\title{
Venture Capital and Career Concerns
}

09 November, 2017

\begin{abstract}
This paper finds evidence that the market for follow-on capital discourages risk taking by venture capital fund managers. The amount of follow-on capital raised by venture capitalists is concave with respect to current fund performance. In addition, managers with less consistent performance are slower, and less likely, to raise a follow-on fund. Venture capitalists adjust their investment strategy to balance fundraising incentives against the incentive to pursue risk provided by carried interest. The findings are consistent with models of career concerns, where an agent's compensation is designed to (partially) offset the implicit incentives created by future employment opportunities.
\end{abstract}

Keywords: Venture Capital, Career Concerns, Agency Problems, Risk Shifting

JEL Classification: G24

\author{
Nicholas G. Crain \\ Assistant Professor of Finance \\ Owen Graduate School of Management \\ Vanderbilt University \\ $40121^{\text {st }}$ Ave South \\ Nashville, TN 37203 \\ nicholas.crain@,owen.vanderbilt.edu
}

\footnotetext{
* This project benefited from the support of the Hicks, Muse, Tate \& Furst Center for Private Equity Finance at the McCombs School of Business. The data for this project was generously provided by Neuberger Berman, with special thanks due to Brien Smith and Joshua Miller. The views expressed in this paper are my own and cannot be taken to represent the views of Neuberger Berman, its management or staff. I thank Burgiss and the Private Equity Research Consortium (PERC) for providing venture capital fund performance benchmark data. This research was supported by the Financial Markets Research Center at Vanderbilt University. Portions of this paper are taken from my dissertation and have benefited greatly from my committee: Robert Parrino, Sheridan Titman, Andres Almazan, Jonathan Cohn and Carlos Carvalho. In addition, I would like to thank Nicholas Bollen, Nicholas Hirshey, Oğuzhan Karakaş and Kelvin Law for their helpful comments.
} 


\section{Introduction}

The institutional features of venture capital and other private equity partnerships require that fund managers, the General Partners (GPs), must return to the fundraising market to raise new capital every 3 to 5 years. In order to raise a follow-on fund, the GP's track record, including the early results from the GP's current fund, must pass muster with the large institutional investors that make up the majority of private equity investors. Such scrutiny may help mitigate agency conflicts between GPs and the investors in the current fund, the Limited Partners (LPs), by providing an implicit incentive for the GPs to expend effort selecting and monitoring portfolio companies that will become part of their track record (Jensen, 1989). ${ }^{1}$ Chung et al. (2012) estimate the magnitude of implicit pay-for-performance is similar to the effect of carried interest, the explicit pay-forperformance GPs receive directly from their current fund. ${ }^{2}$

However, starting with the seminal career concerns model of Holmström (1982), economists have recognized that high-powered implicit pay-for-performance may also distort incentives. Catering to would-be future investors (or employers in a more general setting) may require that agents put too much emphasis on strategies that are likely to preserve their reputation or give the appearance of talent. Often explicit compensation must be designed to compensate for distortions created by implicit incentives (Gibbons and Murphy, 1992). With this framework in mind, this

\footnotetext{
${ }^{1}$ Jensen (1989) describes the potential benefits of leveraged buyout private equity in limiting agency problems. His argument about the value of implicit incentives applies equally to venture capital, which has a similar fund structure.

2 Implicit pay-for-performance or career concerns is used throughout the paper to refer to the expected increase in lifetime income the GPs can expect to earn from increasing the likelihood of raising a follow-on venture capital funds and from raising larger follow-on funds.
} 
paper examines empirical evidence that the market for follow-on funds discourages venture capitalist from pursuing risky investments with their current fund.

Consider, for example, a GP approached by an entrepreneur seeking capital for a venture that is very likely to fail, but also has a small probability of producing an extremely high return. If the returns in the event of success are high enough, funding the venture would be optimal from the perspective of the fund's LPs. However, in the event the venture fails, the performance of the GP's remaining investments may be insufficient to raise a new fund, ending the GP's career as a venture capitalist. The risky investment described would only be made if payoff in the fundraising market (in the event of success) is large enough to compensate the GP for the high probability of failure. But it is unclear why follow-on investors, who care only about the GP's ability to produce returns in the future, would reward the GP with a much larger fund, particularly when the outcome of one particularly successful portfolio company may be more indicative of luck than talent.

To examine how fundraising markets reward venture capitalists for pursuing risk, I evaluate the fundraising success of 207 venture capital funds raised between 1981 and 2008. The data was obtained from Neuberger Berman, a global alternative asset management firm with over 30 years of experience investing in venture capital funds. The data include the quarterly cash flows and valuations for every portfolio company investment made by the sample funds. Using this information, I compute the performance of each portfolio company and the aggregate performance of each fund for every quarter. I identify the timing and size of follow-on funds by matching funds in the sample to Preqin and VentureXpert. 
I first consider the concavity of the relationship between follow-on fund size and the aggregate performance of the fund, measured using Public Market Equivalent (PME), as defined by Kaplan and Schoar (2005). ${ }^{3}$ Because fees in venture capital are proportional to fund size, the committed capital of a follow-on fund is natural proxy for the expected income the GP will receive from successfully raising additional capital. ${ }^{4}$ Further, if the size of the follow-on fund is proportional to perceived talent of the GPs, then the size of the fund is proportional to the lifetime fees expected from operating all future funds (Chung et al., 2012).

I find the market for follow-on venture capital funds punishes poorly performing funds more than it rewards very successful funds. Follow-on fund size is strongly concave with respect to the PME of the current fund measured when the GP was attempting to raise a new fund. This effect is largely driven by GPs who fail to raise any new fund. This result is in line with Kaplan and Schoar (2005), who find a concave relationship between follow-on fund size and the final value current fund's performance.

The concavity result suggests that GPs would benefit from taking less risky investments. However, it's unclear whether the failure of very successful GPs to raise much larger funds is driven by LP's perception of a GP's talent, or is simply an outcome of poor returns to scale, which prevent GPs who are perceived to be very talented from raising a much larger fund. ${ }^{5}$ An advantage of the

\footnotetext{
${ }^{3}$ Results using Internal Rate of Return (IRR) or Total Value over Paid-In (TVPI) are similar and available from the author upon request.

${ }^{4}$ Metrick and Yasuda (2010) document modest variation between funds in fees as a percentage of committed capital.

${ }^{5}$ Hochberg et al. (2014) provide an alternative explanation: that concavity in follow-on fundraising may be driven by a hold up problem, where LPs use their information advantage to demand the GP raise a smaller follow-on fund. Follow-on investors' perception of GP talent plays a role in the hold-up problem, but only because previous LPs
} 
portfolio company-level data is that I can examine whether the distribution of portfolio company performance within a fund is related to fundraising success. If, conditional on the current fund's aggregate performance, follow-on investors reward consistency within a GP's portfolio, this would suggest that follow-on investors are updating their beliefs about the GP's talent conditional on how they perceive the risk of the GP's strategy.

Discussion with LPs suggests they commonly use a fund's loss rate, a measure of the aggregate losses of the fund's poorly performing investments, to assess the amount of risk underlying a GP's individual portfolio companies. ${ }^{6}$ I find that, conditional on performance of the fund in aggregate, fund loss rate is negatively correlated with the likelihood that a GP will raise a new fund, as well as the speed at which they will do so. I find similar results using a Herfindahl index constructed to measure the concentration of portfolio company returns. When aggregate fund performance is driven by a small number of very successful portfolio companies, GPs have more difficulty raising a follow-on fund. Both results suggest that LPs are more likely to attribute a fund's success to GP talent when the performance of portfolio companies within the fund is more consistent. $^{7}$

Given the incentives created by the fundraising market, if GP's only source of pay-forperformance was raising a follow-on fund, they would be unlikely to fund the innovative, high

are perceived to have an information advantage in evaluating the GP. The implication for the optimal strategy of GP is similar to the implications of limited returns to scale.

${ }^{6}$ See Ragazzo (2015) for an industry perspective on fund loss rates.

${ }^{7}$ In unreported results I find no correlation between the standard deviation of portfolio company performance within a fund and fundraising success. This is likely because many of the relatively new investments may still be held near cost at the time GPs are trying to raise a new fund. In contrast, the loss rate and portfolio company concentration measures are mostly determined by portfolio company investments, which have produced some information. 
growth firms commonly associated venture capital. This may help explain why carried interest is structured as a call option on fund performance. The Holmström (1982) model implies that explicit pay-for-performance must often be designed to offset some of the distortion created by implicit pay-for-performance. Accordingly, the convex payoff to carried interest provides the GP an incentive to pursue more risk. The results in this paper don't rule out other explanations for the shape of carried interest. ${ }^{8}$ However, the changing balance between fundraising concerns and carried interest over the life of the fund provides a useful way of identifying the effects of implicit compensation on GP's investment decisions.

Early in the fund each GP must balance the incentive to build a consistent track record against the incentive to maximize the convex payoff to carried interest. As the fund progresses, the balance between these two incentives shifts based on the performance of the fund's early investments. GPs who achieve early success are likely to quickly raise a new fund. Relative to their poorly performing peers, they have little incentive to cater to the fundraising market, and can use the current fund's remaining capital to maximize the value of carried interest.

Consistent with this view I find that GPs with strong initial performance in the current fund pursue riskier investments with their remaining capital. Using a maximum likelihood approach that identifies the relationship between early fund performance and the volatility of subsequent investments, I find that after the first year of the fund, an increase of 0.5 in fund PME is associated

8 One alternative explanation is that structuring carried interest as a call option may be required to receive capital gains treatment as "profits interest" in a partnership. This tax explanation alone seems insufficient, as carried interest existed in its current form before the IRS clarified tax treatment of in 1993 (Goldberg et al., 2013). 
with an increase of $10 \%$ in the variance of subsequent investments. The same increase in initial fund performance corresponds to an $8 \%$ increase in the initial size of portfolio company investments, resulting in less diversification. Results are similar when fund performance is measured using relative performance of funds compared to their vintage year peers. Finally, conditional on fund performance, I find that funds with low loss rates further increase both the variance and size of their subsequent investments. This is consistent with the view that GPs anticipate that loss rates will be used by LPs to evaluate performance, such that low loss rate funds face less risk of raising a new fund. However, I do not find a similar effect for the concentration of portfolio company performance.

In addition to the research mentioned above, this paper relates to the growing literature investigating the incentives of venture capital and private equity fund managers. Ljungqvist, Richardson and Wolfenzon (2007) investigate the propensity of buyout private equity managers to adjust risk in response to implicit incentives. Their intuition is that GPs that have performed poorly will be unable to raise a new fund unless they "catch up" by choosing volatile investments. Empirically, I show that in venture capital, implicit incentives are concave in performance and discourage risk taking. However, my results do not rule out the possibility that a small number of funds may perform poorly enough in early investments that they may expect to fail to raise a new fund without dramatically improving performance. These funds, which may seek out more risk, do not appear to be prevalent in my sample.' Barrot (2016) finds that, following strong performance,

${ }^{9}$ Such a non-monotonic relationship would be consistent with the model of Zwiebel (1995), who shows that under relative performance evaluation, high and low talent managers may pursue risky strategies, while managers with an average level of talent may prefer to behave conservatively. 
venture capital fund managers invest in fewer new investments and select companies that produce fewer patents. He relates his findings to frictions associated with carried interest and the 10 -year limit on the life of venture capital funds. My results do not rule out the possibility that the horizon effects he suggest play a role in GPs investment decisions. However, my finding that (conditional on fund performance) fund loss rates affect GP investment decisions cannot be explained by carried interest, which depends only on the aggregate performance of the fund.

More broadly, this study relates to literature that has used asset management settings to examine the effects of implicit performance incentives. Studies of mutual fund and hedge fund managers have focused on evidence that managers adjust their strategy in response to the convexity of fund flows with respect to performance. (Brown et al., 1996; Chevalier and Ellison, 1997; Brown, et al., 2001). Studying venture capital provides an interesting comparison for several reasons. First, venture capital is a primary market. To the extent the results presented here aggregate, it may affect which types of innovation receive funding. Second, the venture capital setting allows me to test whether sophisticated investors look beyond aggregated fund performance.

\section{Data and Variables}

The sample used for this study consists of the individual portfolio company investments of 207 venture capital funds. The data was provided by Neuberger Berman, a global alternative asset management firm which manages approximately $\$ 11$ billion in private equity commitments that are invested through its private equity fund of funds business. The data was compiled from the quarterly reports provided by each private equity fund that received a commitment from a 
Neuberger Berman fund of funds from 1981 through 2014. Each investment-quarter observation contains the cash flows between the fund and portfolio company and the end-of-quarter valuation of the fund's investment in the portfolio company.

The data has three advantages for studying the performance of venture capital GPs. First, unlike many commercial sources of portfolio company information, the fund of funds' data contains the actual outcomes from each portfolio company investment exited by the end of the sample period in June 2015. For investments that are still active at the end of the sample, performance is calculated using the final valuation reported by the GP. Second, the interim performance of each portfolio company investment and fund can be observed quarterly. Finally, the method in which the data was gathered ensures that concerns about the representativeness of the data are no worse, and possibly better, than for other sources of portfolio company data. Several recent studies use portfolio company data collected from the marketing materials of GPs attempting to raise a followon fund (Braun et al., 2016; Lopez-de-Silanes et al., 2015). These studies focus on cross-sectional research questions because of concerns that data collected may be more likely to sample successful GPs who believed their track record was sufficient to raise a follow-on fund. In contrast, the fund of funds sample contains investments whose outcomes were unknown when Neuberger Berman decided to commit capital to the fund. ${ }^{10}$ Representativeness of the fund of funds sample may still be a concern for some research questions, as the data is provided entirely by one LP, who is

\footnotetext{
${ }^{10} \mathrm{I}$ screen out secondary investments, which are positions in a fund purchased from an existing LP after the fund has been operating for some time.
} 
common to all the funds in the sample. Similar to the studies listed above, this study focuses on cross-sectional results that would be difficult to explain with selection bias.

For this study I limit the sample to funds that received a commitment from Neuberger Berman prior to 2008. This ensures that the majority of investments from each sample fund have been realized. I exclude secondary investments, investments in sidecar funds and funds with less than five portfolio companies. The resulting sample contains nearly twice as many venture capital funds (207) as buyout funds (113); thus, while much of the motivation could apply equally to buyout or other forms of private equity, this project focuses exclusively on venture capital.

\subsection{Variable Construction}

The tests of career concerns below primarily focus on investor response to the interim performance of each GP's current fund. I obtain the aggregate performance of a fund in a given quarter by summing up the previous cash flows from each portfolio company to get a quarterly stream of gross cash flows at the fund level, and by summing up the quarterly value of each portfolio company investment to get the fund's gross NAV. For each fund-quarter, I calculate the gross PME using the method of Kaplan and Schoar (2005). Except as noted below, PME is calculated using the value-weighted return of NASDAQ stocks in the Center for Research in Security Prices data (CRSP).

Because historical venture capital performance is cyclical, I also measure the relative performance of each fund using the vintage year venture capital fund PME quartile breakpoints 
provided by Burgiss. ${ }^{11}$ The Burgiss Manager Universe is sourced exclusively from limited partners and is one of the largest samples of fund performance data available for academic research (Harris et al., 2014). Two adjustments are required to compare performance of the sample funds to the Burgiss breakpoints. First, the sample funds must be adjusted for management fees and carried interest, as the Burgiss database is derived LP cash flows and valuations, which are net of these fees. To estimate a comparable set of LP cash flows from the fund-of-funds data, I assume a management fee and carried interest structure consistent with the average venture capital fund documented in Metrick and Yasuda (2010). Appendix A contains details of the fee adjustment. Second, I calculate PME for these estimated LP cash flows using the Russell 3000 as a public benchmark to be consistent with the method used by Burgiss.

The Loss Rate is a measure used by LPs as an indication of the amount of risk taken by the fund managers. The intuition behind the measure is that a GP who creates the same aggregate performance from investing in more risky portfolio companies will experience a higher proportion of losses. It is calculated by focusing on the dollar amount lost in portfolio company investments that have negative returns since inception divided by amount of capital deployed by the fund:

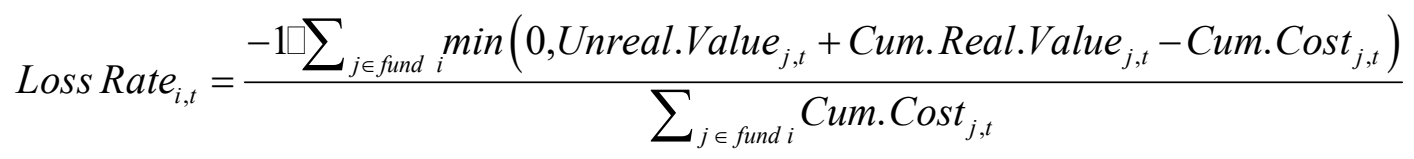

The numerator represents the sum of the dollar losses among all portfolio company investments in the portfolio of fund $i$ that have negative cumulative returns. Unreal. Value $e_{j, t}$ is the

\footnotetext{
11 Vintage year refers to the year in which the first closing of the fund was held.
} 
valuation of an unrealized position in portfolio company $\mathrm{j}$ in quarter $\mathrm{t}$. Cum. Real. Value is the cumulative realized value, the cash flows from the portfolio company to the fund as of time t. Cum. Cost is the cumulative cost, the cash flows from the fund to the portfolio company as of time t. The denominator is the cumulative cost of all investments the fund has made as of time t.

While Loss Rate captures the extent to which the GP's investment strategy created losses, it offers no information about the gains in the portfolio. Given the same aggregate fund performance and loss rate, LPs may still be more cautious committing capital to a GP whose previous success is predominantly driven by a small number of successful investments. To proxy for the extent to which the fund's performance is concentrated in a small number of successful investments, I form a Herfindahl-Hirshman Index (HHI) based on the individual contribution of each investment to the aggregate performance of the fund. The share of the fund's value attributable to investment $j$ at time $\mathrm{t}$ is given by:

$$
S_{j, t}=\frac{\text { Unreal. }_{\text {Value }}^{j, t}+\text { CumReal.Value }_{j, t}}{\sum_{j \in \text { fund }_{i}}\left(\text { Unreal.Value }_{j, t}+\text { Cum Real.Value }_{j, t}\right)}
$$

The Porffolio Company HHI is then computed each quarter by summing the squared share of each portfolio company in fund $i$.

$$
\text { Portolio Comp } H H I_{i, t}=\sum_{j \in \text { fund } i} S_{j, t}^{2}
$$




\subsection{Descriptive Statistics}

Table 1 provides the descriptive statistics of the venture capital funds in the sample. Panel A describes the moments of the data at the fund-level. GPs in the sample have a diverse level of experience. The GP of the median fund in the sample has operated 2 previous funds, with the most experienced GP having operated 11 previous funds. ${ }^{12} 36$ of the funds, $17.4 \%$, are managed by a GP operating their first fund. Fund Size is measured as the aggregate capital committed by the fund's limited and general partners. Fund Size is right skewed, with mean fund size of $\$ 285.2$ million and a median value of $\$ 150.0$ million. Skewness is less evident in the number of portfolio company investments made by each fund. The mean and median number of investments made by each fund is 33.9 and 29 respectively.

The fund performance in the sample seems slightly tilted towards better funds, with the mean performance skewed by a few very high performing funds. The mean and median final PME of funds in the sample are 1.60 and 1.13 respectively, suggesting that gross-off fees performance exceeded that of public markets. PME Quartiles are ordered from lowest (1) to highest (4) such that a fund randomly drawn from the Burgiss database would have an expected PME Quartile of 2.5. The mean and median PME Quartile are 3.02 and 3.00 respectively, slightly higher than in the Burgiss database. Two of the funds in the sample were raised prior to 1983, the first year in which Burgiss

12 The number of previous funds was inferred from the series number of the fund (i.e. the GP of the fictional fund ACME VII LLP would be assumed to have operated six previous funds). For GPs whose funds are not numbered sequentially, the number of previous funds was determined by counting the number of previous funds listed in VentureXpert and Preqin. 
breakpoints are available. The median IRR for funds in the sample is $15 \%$, with IRR Quartile distributed similarly to PME Quartile.

The median final Loss Rate is $41 \%$, consistent with the view that the portfolios of venture capital funds contain many investments that suffer significant losses. However, there is also significant heterogeneity in the Loss Rate, which varies from as little as $4 \%$, to as much as $91 \%$. Final fund Loss Rate has a correlation of -0.10 with final fund PME, which is not statistically significant at standard levels. This suggests that fund loss ratio contains a significant amount of information that is independent of aggregate fund performance.

The median final Portfolio Company HHI is 0.14. This is in line with the typical view that the returns of many venture capital portfolios are largely driven by a small number of successful investments. For comparison, a fund making the median number of investments, 29, with all of the investments having equal performance would result in a Portfolio Company HHI of 0.034. Portfolio Company HHI has a correlation of 0.20 with Fund PME, which is significant at the $5 \%$ level. This is largely driven by funds that have one or two extremely successful portfolio companies, which dominate the portfolio and create high returns for the fund overall. The correlation between Portfolio Company HHI and PME Quartile is 0.01 and not statistically significant.

Information on follow-on funds raised by each fund GP was compiled by examining the fund of funds data, Preqin and VentureXpert. When no follow-on fund could be found in each of those databases, a web search was used to ensure there was no evidence that the GP has raised a follow-on fund. $81.2 \%$ of sample fund GPs (168 out of 207) were successful in raising a new fund. 
Panel B of Table 1 contains descriptive statistics of the follow-on funds. The median follow-on fund was raised 3.25 years after the current fund, and was 1.38 times larger than the current fund. Panel B also presents descriptive statistics for the GP's performance in the current fund in the quarter prior to raising the follow-on fund. The aggregate performance of these funds is similar to the final performance of all funds in the sample. However, both the Loss Rate and Portfolio Company $H H I$ are much smaller, as at the time a GP raises a new fund, many of the current portfolio companies are relatively new and have yet to produce gains or losses.

Table 2 contains descriptive statistics on the portfolio companies in the sample. The data contain 9,752 distinctly identified investments. 85 investments that appear to be something other than a portfolio company, such as "Currency Forward", "Other", "Miscellaneous" or "Undisclosed", are excluded from the portfolio-company analysis, but are used to in the computation of aggregate fund performance. Investments labeled as "Escrow", investments that have cost less than $\$ 25,000$, investments that take place more than 8 years into the fund, or that have a holding period of less than one quarter are first examined to see if they appear to be related to another portfolio company through a spin-off or merger. This is accomplished by comparing investment entry and exit dates, searching the web for news on the relevant companies and by examining GP quarterly reports, which are available after the $4^{\text {th }}$ quarter of 2004 . This results in 2,197 linked investments. An additional 558 investments meet one of the criteria above, but cannot be linked to another portfolio company. These are excluded from the portfolio company analysis, but included in the calculations of fund aggregate performance. The final sample contains 6,912 portfolio companies. 
Initial investment size is measured over the first 9 months of the relationship between a fund and portfolio company. ${ }^{13}$ The median investment size is reasonably large, over $\$ 2.3$ million or $1.2 \%$ relative to the size of the fund. The distribution is right skewed, with some very large initial investments made by late-stage venture capitalists, including one investment of $\$ 90$ million. $91 \%$ of the portfolio company investments have exited at the time the sample was collected. The median holding period of investments is 4.8 years, which matches the view that venture capital assets have a relatively long duration. The data does contain a small number of observations with holding periods greater the 10 years, which is consistent with the view that the limited life of venture capital funds can be extended when no option exists to liquidate an asset.

PME for each investment is calculated relative to the value-weighted return on NASDAQ stocks in CRSP. The median PME in only 0.48, suggesting that most investments perform poorly. However, the distribution is extremely right skewed with mean PME of 1.73. As might be expected, the sample's skewness contrasts with the buyout fund samples of Lopez-de-Silanes et al. (2015) and Braun et al. (2016), in which portfolio companies have median PME of 1.27 and 1.4 respectively. IRR and Multiple of Invested Capital (MOIC) at the portfolio company level paint a similar picture. ${ }^{14}$

\footnotetext{
13 This accounts for instances when a fund investment in a single round appears to have been metered out over several quarters, and instances where a fund appears to have made a small bridge loan or other transaction in anticipation of a larger round that followed shortly.

${ }^{14}$ Unique IRR calculations for 276 investments were not possible due to multiple sign changes in quarterly cash flows.
} 


\section{Fundraising Incentives to Take Risk}

In this section I examine how the interim results of the manager's current fund investments are related to success in a raising follow-on fund. The analysis focuses on two channels through which the follow-on fund market might discourage the GP from pursuing risk. First, I consider whether the expected payoffs in the fundraising market, relative to the aggregate performance of the

fund, are concave. Second, conditional on aggregate fund performance, I consider whether fund managers penalized for inconsistent performance among the investments in their portfolio.

\subsection{Fund Performance and Follow-on Fund Size}

Figure 1 plots the relationship between fund performance and the increase in size of the GP's follow-on fund observed in the sample. Figure 1A includes all the funds in the sample, while Figure 1B omits the extremely successful funds with PME $>3$. In each plot, the horizontal axis describes the PME of the fund in the quarter before a new fund was raised. The vertical axis measures the increase in fund size, calculated as capital committed to a follow-on fund divided by the committed capital of the current fund. For instances where the GP did not successfully raise a follow-on fund, Size Increase is set to zero and fund PME is measured at 5 years into the fund, roughly one standard deviation later than the average follow-on fund is raised. Each scatter plot represents individual observations and is overlaid with a conditional mean function and standard error bounds estimated via Loess smoothing.

The smoothed plot in Figure 1A shows strong evidence of the concavity of follow-on fund size with respect to PME of the current fund. Figure 1B demonstrates that the concave pattern 
remains even after the outliers with extremely high interim performance are excluded. The current fund performance of GPs who did not raise a follow-on fund are concentrated around a PME of 1.0 or lower. As fund PME increases, the likelihood of raising a new fund increases, driving up the conditional expectation for follow-on fund size. However, conditional on raising a new fund, it's not clear that higher performance results in a substantially larger fund. This is especially clear for extremely successful funds, those with a PME of 2.0 or greater. The GPs of these funds all successfully raised a new fund, but the size increase does not appear to be substantially greater then moderately performing funds who successfully raised a new fund.

Figure 2 replicates the plots in Figure 1, omitting the funds of GPs who did not successfully raise a new fund. In both Figure $2 \mathrm{~A}$ and $2 \mathrm{~B}$ the smoothed relationship between PME and follow-on fund size has a modest positive slope. This suggests that, conditional on raising a new fund, the increase in fund size appears only weakly related to performance. It also suggests that the concavity evident in Figure 1 is strongly driven by the extensive margin, the GPs failed to raise a new fund.

To provide further evidence on the relationship between aggregate fund performance and follow-on fund size I regress the increase in fund size against measures of interim fund performance and other controls. To control for the boom and bust cycles evident in venture capital returns, regressions with $P M E$ include additional fixed effects for the vintage year in which the current fund was raised. As an alternative to PME, some specifications focus on PME Quartile, a measure of the relative performance of each fund measured the quarter before a follow-on fund is raised. 
Panel A of Table 3 reports regression estimates, with funds who failed to raise a new fund assigned a zero, and their performance measured five years into the fund. Fund performance is measured as either PME or PME Quartile and is indicated at the top of each specification. Because small funds have more opportunity to grow than larger funds, the natural log of fund size is included as a control variable. GP Experience, defined as the natural log of one plus the number of previous funds operated by the GP, is also included as a control.

In Model 1, the coefficient on PME is 0.12 . While statistically significant, the economic size of the effect is modest. An increase of 0.5 in PME would only result in a 6\% larger fund. ${ }^{15}$ Adding the square of PME in Model 2 improves the performance of the model and confirms the concave relationship evident in Figure 1. Both the positive coefficient on PME and the negative coefficient on squared PME are highly statistically significant. The $\mathrm{R}^{2}$ of the model nearly doubles to 0.115 . The marginal effect suggests that, when the fund's performance is modest, a subsequent increase in performance has a strong effect on the expected size of the follow-on fund. For a fund with PME of 1.0 the economic effect of the squared term is small, such that the marginal effect of PME is 0.47 , roughly 4 times the estimate from Model 1. The negative coefficient on the squared PME term is negative and significant at the 5\% level.

Measuring performance with PME Quartile also suggests a strong effect of performance on expected follow-on fund size. Moving up one quartile relative to other funds from the same vintage

${ }^{15}$ Because PME is very skewed, throughout the paper I focus on PME change of 0.5 when assessing economic magnitude of its marginal effects. This is approximately the difference in PME between the median and $75^{\text {th }}$ percentile of final fund PME. 
year increases the expected size increase of a follow-on fund by a factor of 0.34 . Specifications with squared PME Quartile terms are omitted because the coarseness of the quartile breakpoints creates a multi-collinearity problem.

The analysis also examines the correlations between GP Experience and follow-on fundraising. Potential follow-on investors may put less weight on the performance of the current fund when evaluating GPs with long track records. On the other hand, the skills required to evaluate new innovation and technology may change frequently, such that investors put the most weight on a GP's recent performance. In each model from Panel A, the coefficient on GP Experience is weakly positive, but only statistically significant at the 5\% level in Model 3 and 6. Models 4-6 include an additional interaction term between fund performance and experience to examine whether fundraising outcomes for more experienced GPs are potentially less sensitive to performance of the current fund. Only Model 6, which uses PME Quartile and omits vintage year fixed effects, results in a negative and moderately significant interaction term. These results provide some support for the view that the fundraising success of more experience GPs is less dependent on the performance of their current fund. However, because the industry is relatively young and very experienced GPs only occur in late in the sample, the effects of GP Experience is difficult to separate from vintage year.

Panel B of Table 3 omits funds in which the GP did not successfully raise a follow-on. In these specifications the marginal effects of fund performance and other variables can be interpreted as being conditional on the GP successfully raising a new fund. Consistent with the visual pattern evident in Figure 2, the estimated relationship between fund performance and follow-on fund size is 
much weaker. The coefficient on PME and its square term are insignificant in all the models in Panel B, with the exception of Model 4. When an interaction with GP Experience is included in Model 3 and 4, PME has a modest positive marginal effect on the follow-on fund size for more experience funds. In contrast, relative fund performance, PME Quartile, is statistically significant, but with roughly half the magnitude observed in Panel A. The results suggest the extensive margin, whether the GP raises any follow-on fund or not, explains much of the correlation between aggregate fund performance and follow-on fund size and drives the concavity evident in Figure 1.

\subsection{Existence of a Follow-on Fund}

In Table 4, rather than focus on the size of follow-on fund raised by the GP, I focus exclusively on whether the GP will successfully raise a follow-on fund given their performance. The sample consists of 147 funds who had not raised a follow-on fund by 3 years. This ensures that the fund has been operating long enough to generate some information about the success of their portfolio companies, while still ensuring that enough funds remain who have not yet raised a new fund. ${ }^{16}$ The dependent variable is an indicator that takes the value 1 if the GP successfully raises a new fund at any point after three years. I estimate a linear probability model because the specifications of interest include both interaction terms and fixed effects making probit results difficult to interpret (Ai and Norton, 2003). Unreported probit estimates that omit any interactions

\footnotetext{
${ }^{16}$ Appendix Table $\mathrm{C} 1$ repeats the analysis in this section at two and four years into fund life.
} 
and fixed effects produce similar estimates of the coefficients associated with the remaining variables.

The first two models in Table 4 consider the effect of fund performance, as well as the experience of the GP on successfully raising a new fund. Both PME and PME Quartile are positively associated with raising a new fund. For a first-time GP, an improvement in PME of 0.50 is associated with a $41 \%$ increase in the change of raising a new fund. Similarly, increasing relative performance from one PME Quartile to the next increases the odds of raising a new fund by 25\%. GP Experience is also positively related to performance. The interaction term between fundperformance and experience strongly negative in each specification. Taken together, the results suggest that performance of the current fund is positively associated with success in raising a new fund, but that the effect declines with GP Experience.

Models 4 through 6 repeat the analysis adding either Loss Rate or Portfolio Company HHI. As described in Section 2.1, both measure provide information about the distribution of portfolio companies in the fund's portfolio. In each specification they are included along with fund performance, so that their coefficients can be interpreted as a marginal effect conditional on fund performance. Consistent with the view that LPs view funds with high loss rates skeptically, the Loss Rate is strongly negatively related to the likelihood of raising a new fund. Conditional on the same fund PME, the coefficients in Model 3 suggests that a one standard deviation increase in Loss Rate for funds in year $3(0.17)$, is associated with a $23 \%$ decrease in the likelihood of raising a new fund. The coefficient on Loss Rate in Model 4, where PME Quartile is used to measure relative performance, is similar, which suggests that Loss Rate is not simply picking up an effect of concavity. 
Estimates in Model 5 and 6 suggests that Portfolio Company HHI has a similar effect. A one-standard deviation increase of Portfolio Company HHI at 3 years (.09), is associated with a 10 to $16 \%$ decline in the likelihood of raising a new fund.

In summary, the results suggest that success in raising a new fund depends on both aggregate performance of the current fund and the distribution of success among the current fund's individual investments. The negative association between success in raising a new fund and both Loss Rate and the Portfolio Company HHI further suggest that LPs view consistency as evidence whether a GPs performance should be attributed to talent or luck. GPs anticipating such an effect would benefit from pursuing less risky portfolio companies, which are more likely to produce consistent performance.

\subsection{Speed of Follow-on Fund Raising}

The evidence in the previous section shows that implicit career incentives are largely determined by the discrete impact of crossing the threshold required to raise a new fund. Conditional on raising a new fund, the additional marginal benefit for performance is small. Given these conditions, it is intuitive that a GP will raise a follow-on as soon as their track record permits. In this section I employ a Cox proportional hazard model to examine the empirical relationship between current fund performance and the speed at which GPs raise a follow-on fund. This semiparametric approach does not require a parametric functional form for the baseline hazard model, 
while retaining an easy-to-interpret parametric form for the proportional effects of the explanatory variables. $^{17}$ In the Cox model, the functional form of the hazard rate is given by:

$$
\lambda\left(t, x_{i}\right)=e^{x_{i} \beta} \lambda(t)
$$

$$
\lambda\left(t, x_{i}\right) \text { represents the hazard rate at which the GP of a fund with characteristics } x_{i}
$$

at time $\mathrm{t}$ raises a new fund. $\lambda(t)$ represents the baseline hazard rate at which GPs raise a new fund $\mathrm{t}$ quarters into their current fund.

The dependent variable is the duration of time from the first closing of the current fund until the first closing of a follow-on fund, measured in quarters. The primary explanatory variables are fund performance and GP Experience. To control for changes in the institutional appetite for investing in venture capital, I include the count of the number of funds listed in Preqin raised in the year prior to the current quarter. For specifications that use PME to measure performance, the analysis is stratified by vintage year to control for unobserved heterogeneity across time. $^{18}$

Table 5 presents the results relating the performance of the current fund to the speed at which a new fund is raised. The coefficients are hazard ratios associated with a change in each dependent variable. Both PME and PME Quartile are positively associated with the speed at which a GP raises a follow-on fund. The coefficient on PME Quartile in Model 2 suggests that increasing

\footnotetext{
17 The Cox proportional hazard model is a common model of duration. Examples of its use in the venture capital literature include Hellman and Puri (2000, 2002) and Lerner, et al., (2003).

18 Stratification by vintage year allows for different baseline hazard functions for each vintage year, while requiring the coefficient estimates to be the same across years.
} 
relative performance by one quartile increases likelihood of raising a new fund in the next quarter by a factor of 2.05. Regressions that use PME suggest that GP Experience is positively associated with the speed at which a GP raises a follow-on fund, and that the GP's follow-on fund raising is less sensitive to performance. However, when performance is measured with PME Quartile the coefficients on GP Experience are weak and no longer significant.

The hazard ratios associated with the Loss Rate in Models 3 and 4 suggest that GPs with higher losses in their current portfolio must wait longer to raise a new fund. The hazard ratio in Model 3 suggests that a one standard deviation increase in the Loss Rate (0.108), is associated with factor 0.64 change to the likelihood of raising a new fund in the next quarter (i.e. a 35\% decrease in the relative probability of raising a new fund). There is little change in the coefficient associated with PME between Models 1 and 3, and a large increase in Pseudo- $\mathrm{R}^{2}$. Similarly, the hazard ratios associated with Portfolio Company HHI in Models 5 and 6 suggest that GPs whose gains are concentrated in a relatively small number of portfolio companies will require longer time before they will be able to raise a new fund. A one standard deviation increase in Portfolio Company HHI (.216), is associated with a factor change in the probability of raising a new fund in the next quarter of 0.30 and 0.57 for Models 5 and 6 respectively.

The hazard model results parallel those from previous analysis of the relationship between GP performance and fundraising outcomes. GPs with better fund performance are expected to raise a fund sooner. However, conditional on a given level of performance, GPs who show large percentage of losses, or those whose gains are derived from a more concentrated group of winners will take longer to raise a new fund. This is consistent with the view that LPs are more reluctant to 
attribute strong fund level performance to skill when the performance of portfolio companies within a GPs portfolio is inconsistent. The results also re-enforce the intuition that GPs with strong performance have less incentive to cater to fundraising markets when making their subsequent investments. These GPs will raise a fund sooner than their peers, so that there is less chance that any subsequent investment will demonstrate failure (or success) before a follow-on fund is raised.

\section{GP Risk Taking Behavior}

This section examines the investment choices of venture capital GPs for evidence that they adjust their strategy in response to career concerns. Identification follows from the results in the previous section, which suggest that funds whose initial investments perform well have much less incentive to continue catering to future investors than funds whose initial investments perform poorly.

Early in the fund, each GP must weigh the incentive to avoid risk created by the fundraising markets against the incentive to maximize the convex payoff to carried interest. As the fund progresses, the balance between these two incentives shifts based on the performance of the fund's early investments. GPs who achieve consistent success early in the fund are likely to raise a followon fund based on their early investments alone, and to do so quickly. Their subsequent investments with the current fund are unlikely to affect their ability to raise a follow-on fund, but remain important for determining carried interest. This suggests that positive performance early in the fund, and more consistent performance, should be associated with riskier strategy regarding remaining capital. 
I explicitly evaluate two channels by which the GP can pursue higher risk. In Section $4.1 \mathrm{I}$ demonstrate a positive correlation between early fund performance and the individual variance of subsequent portfolio company investments selected by the GP. Section 4.2 demonstrates a similar relation between early fund performance and the size of subsequent investments (implying less diversification). ${ }^{19}$

\subsection{Portfolio Company Volatility}

Providing evidence on variance of individual venture capital investments is challenging because we do not observe a time series of returns for each investment as we would with public securities. The fund of funds data contains the time series of valuations reported by the GP, but these are updated infrequently, and the resulting measures would almost certainly be noisy and heavily biased toward low variance. Instead, I focus on the cross sectional relationship between variables related to the strength of career concerns and variance in the final outcome of portfolio company investments. I evaluate the following empirical model using maximum likelihood estimation:

$$
\begin{gathered}
P M E_{i, j}=\max \left[0, \mu_{i}+\grave{o}_{i, j}\right] \\
\grave{o}_{i, j} \sim N\left(0, \sigma_{i, j}^{2}\right)
\end{gathered}
$$

${ }^{19}$ Portfolio variance may also be increased by selecting more correlated investments. Given the nature of the data developing a powerful test to investigate this channel remains difficult and may motivate further study. Unreported results suggest that GPs do not respond by adjusting industry or geographic diversity of their portfolio through subsequent investments. 


$$
\sigma_{i, j}^{2}=e^{\theta_{i}+\beta X_{i, j}}
$$

The dependent variable in each observation is the final PME realized for one portfolio company investment. The subscript $i$ is used to index individual GPs, while the subscript $j$ is used to index individual portfolio company investments for each GP. The model is similar in spirit to the multiplicative heteroskedasticity model of Harvey (1976). The variance of each portfolio company investment is treated as a latent variable, which is computed by maximizing the likelihood function derived in Appendix B. In addition, the model accounts for truncation at PME of 0 (-100\% return) with a correction that is analogous to a Tobit model. A similar approach may be used in other corporate finance applications where the goal is to draw inference about the cross-sectional variance, but where each observation has only a single outcome. For example, Lowry, Officer and Schwert (2010) use a similar model to estimate the effects of information asymmetry on the variance of IPO initial returns, where each IPO has only a single first day return.

The main explanatory variables in $\mathrm{X}_{\mathrm{i}, \mathrm{j}}$ of Equation 7 are measures of fund performance and portfolio company consistency (PME, PME Quartile, Loss Rate and Portfolio Company HHI) in the quarter before the portfolio company investment was made. Because measures of fund performance are likely to be uninformative very early in the fund (before any of the fund's investments have had sufficient time to succeed or fail) the analysis excludes investments made during the fund's first year. Both Equation 5 and Equation 7 contain dummy variables for the GP so that the coefficients on the main explanatory variables are unlikely to be driven by unobservable 
differences in GP talent or strategy. ${ }^{20}$ GP Experience and the log of fund age at the time of the portfolio company investment are included as additional controls in Equation 7.

Table 6 presents results from estimating the model. Each model reports the coefficients of $\beta$ in Equation 7, the variance equation. The results from each model suggest that GPs who have performed well take relatively more risk in their remaining portfolio company investments. The coefficient of 0.23 on PME in Model 1 suggests a 0.5 increase in fund PME before the investment is made is associated with a $11.5 \%$ increase in the variance of the investments. Estimating the model with PME Quartile produces a similar result. The estimates in Model 2 suggest that increasing relative fund performance by one quartile is associated with a $12 \%$ increase in the variance of subsequent investments.

Models 3 and 4 include the Loss Rate measured in the quarter prior to the investment. The results in previous sections suggest that funds with higher loss rates face more difficulty raising a new fund. All things equal, GPs with higher loss rates may anticipate that their next investment will have more impact on their ability to successfully raise a new fund. Consistent with this view, the estimate in Model 3 suggests that one standard deviation in Loss Rate (0.124) corresponds to a 19\% decline in the variance of subsequent investments. The final two specifications in Table 6 include the lagged Portfolio Company HHI. Following the same intuition as with Loss Rate we would expect GPs to pursue less volatile investments if their current fund performance is concentrated in a small

${ }^{20}$ Note that dummy variables are based on the GP and are common for all the GP's funds. This controls for unobserved GP-level heterogeneity, while greatly reducing the numerical difficulty of finding a converging solution to the model. Numerical solutions with additional dummy variables for investment year did not consistently converge. 
number of successful investments. However, the estimates are positive. Only the coefficient on Portfolio Company HHI in Model 6 is significant at greater than $10 \%$, such that there is little evidence that GPs are adjusting the portfolio company strategy relative to Porffolio Company HHI.

Each of the models in Table 6 also includes the log of years into the fund as an explanatory variable, but the coefficient changes sign across different models, and is only strongly statistically significant in Model 3. In contrast, the results suggest that GP Experience is strongly negatively related to variance. While the finding is interesting, the implication for the career concerns hypothesis is ambiguous. On the one hand, evidence from the previous section suggested that GPs with more experience have an established track record from prior funds, and may face less need to demonstrate talent to potential follow-on fund investors. This would suggest experience GPs may be free to pursue riskier investments. On the other hand, given all things equal, that experienced GPs are more likely to raise a follow-on funds suggests that their continuation value of raising a new fund is higher. Said another way, the relative cost to not raising a follow-on fund may be higher for experienced GPs, leading to less risk taking. The negative coefficient on GP Experience is consistent with the latter interpretation.

\subsection{Investment Size}

In addition to investing in riskier portfolio companies, GP's may diversify their portfolio by making smaller investments in a larger number of portfolio companies. Given the skewed distribution of venture capital returns, diversifying through smaller investments would both reduce loss rate going forward and reduce the likelihood that fund performance is concentrated in one or two portfolio companies. Unlike portfolio company risk, investment size can be directly 
observed so that the econometrics are relatively simple compared to the analysis in the previous section. I focus on initial investment size because venture capitalists often stage portfolio company investments to preserve the option to abandon companies that perform poorly following with the initial round of capital. The initial investment size is more representative of the amount of capital the GP was willing to risk on a given portfolio company at the time the initial investment decisions was made.

Table 7 presents OLS estimates of the relationship between early performance of a fund and the size of subsequent portfolio company investments. The dependent variable is the size of the initial investment in each portfolio company measured as a percentage of the total size of the fund. Lagged fund performance is measured as either PME or PME Quartile, as in the previous sections. All specifications include GP fixed effects and additional controls for the log of fund size, log of years into the fund, and the GP's level of experience. An additional concern in this analysis is that the very last investment of the fund may be determined simply by the amount of the capital remaining, rather than the dynamics of compensation and career concerns. To mitigate this affect I identify the last quarter in which each fund makes a new investment and remove all the investments in this quarter from the analysis. This reduces the number of observations to 4,575 and 4,500 when PME and PME Quartile is available respectively.

The results from Models 1 and 2 demonstrate a significant positive association between fund performance and the size of subsequent investments. The coefficient of 0.25 in Model 1 suggests that 0.5 increase in PME is associated with an increase in initial investment size going forward of $0.125 \%$ of fund capital for each subsequent investment. Similarly, the coefficient in Model 2 
suggests an improvement of one quartile in relative performance is associated with a $0.11 \%$ increase in subsequent investment size relative to the size of the fund. These effects are economically meaningful given that the median initial investment size is $1.2 \%$ of the fund capital.

The coefficient on the log number of years into the fund is negative and significant. This may be because funds are trying to balance the subsequent capital needs of their existing portfolio companies against the opportunity to make new investments. Note that this channel cannot explain the relationship between fund performance and investment size, as it would predict that GPs with initial success would make smaller future investments to preserve capital for follow-on rounds of their successful portfolio companies. The coefficient on GP Experience is also negative and significant. This parallels the results in Table 6, which suggest that more experienced GPs make investments with relatively less variance. The coefficient on Fund Size is not significant. This suggests that even as funds get larger, they pursue larger investments on average, such that the percentage of the fund they allocated to each investment is relatively consistent.

Models 3-6 add measures of the distribution of the portfolio companies within each fund to the analysis. Fund Loss Rate is negatively related to subsequent investment size. The coefficient in Model 4 suggests that one standard deviation in Loss Rate (0.124) is associated with a decrease of $0.11 \%$ in the size of subsequent investments, which is large relative to the $1.2 \%$ median investment size. This is consistent with the view that GPs with high loss rate anticipate they may have difficulty raising a follow-on fund, and must continue to pursue a relatively diverse strategy. However, the coefficient on Portfolio Company HHI in Models 5 and 6 is positive, and only significant at the $10 \%$ 
level in Model 6. This result is similar to the result in Table 6 that GPs appear to adjust their strategy to the Loss Rate, but not the concentration of fund returns.

\section{Conclusion}

As better data becomes available, the venture capital and private equity literature is increasingly focused on understanding the economic incentives facing fund managers, and the resulting effects on the portfolios they select. This paper uses a unique data set to document several new stylized facts. First, I confirm the finding in Kaplan and Schoar (2005) that the size of the next fund raised by the GP is concave in the performance of the current fund, and I demonstrate that this relationship is largely driven by the effect of successfully raising a new fund, rather than an increase in fund size conditional on raising a new fund. Second, I show that GPs with more consistent performance among the investments in their current fund are more successful at raising a new fund. This suggests that LPs use the distribution of portfolio companies to infer the risk underlying the GPs strategy, and to help attribute performance to luck or talent. Finally, I show that venture capital GPs appear to adjust their investment strategy in response to incentive to avoid risk created by the market for follow-on funds.

As discussed in the introduction, these findings stand in contrast to the relationship between early performance, and subsequent investment choices, documented for mutual fund managers. This is a particularly interesting comparison because mutual fund managers and venture capital GPs perform a similar role in financial intermediation function. This suggests that the differences in behavior are linked to the institutional details surrounding these two forms of delegated portfolio 
management. The most salient of which is the difference between the fund-raising incentives to avoid risk for venture capital GPs documented in this paper, and the convex performance to fund flow relationship documented for mutual funds.

This paper also makes a contribution to the literature on which types of firms receive venture capital funding. This literature typically focuses on demand-side effects related to the characteristics of the firms. This paper is novel in that I suggest that the firms which receive funding may in part be determined by the implicit career incentives of the GPs. An interesting extension of this work would be to consider whether the effect documented in this paper might have an aggregate effect on the type of ventures which receive funding. Rhodes-Kropf and Nanda (2013) document that during private equity booms, when recent returns have been high and available capital is plentiful, venture capital funds tend to invest in more volatile and more innovative firms. In a separate paper, Rhodes-Kropf and Nanda (2016), propose that this relationship stems from the GP's uncertainty about the ability of the venture to receive follow-on financing from a third-party. This provides a potential alternative channel by which the performance of GPs might affect the aggregate level of innovation in the economy. 


\section{Appendix A: Adjustment of Gross Fund Performance for Fees}

This appendix describes the methodology used to adjust the gross fund performance to account for fees charged by the GP. The adjustment is necessary so that performance of sample funds can be compared with the net-of-fees quartile breakpoints provided by Burgiss which are derived from cash flows to and from fund LPs.

To estimate the LP cash flows from the sample funds, I apply an estimated management fee and carried interest to the gross cash flows available in the fund of funds' data. The estimate fund schedule follows the evidence from Metrick and Yasuda (2010). They find that cumulative management fees in venture capital average $17.55 \%$ of the fund's committed capital. To approximate the effect of the average management fee on cash flows experienced by a funds LP's I subtract an additional $0.5 \%$ per quarter (2\% per year) for the first five years of the fund's gross cash flows, which drops to $.3875 \%$ per quarter (.3875 per year) through the $10^{\text {th }}$ year of the fund. For carried interest, I assume a carry rate of $20 \%$ with a $0 \%$ preferred return and no catch-up provision. Some funds may have a preferred return as high as $8 \%$, such that my fee schedule may understate the performance of these funds relative to actual performance experience by LPs. However, the effect should be small because many of the funds with higher preferred returns are likely to have a catch up provision, where the GPs will receive all of additional profits of the fund past the preferred return until their share of the profits returns to $20 \%$.

For each quarter I calculate the dollar amount that must be returned to LPs such that they would receive the preferred return. If the cash flows returned to LPs from liquidating portfolio 
companies in the current quarter are greater than the amount required to hit the preferred return, then $20 \%$ of the additional cash flows are assumed to go to the GP. Similarly, the sum of cash flow returned to the LP in the current quarter plus the NAV of the fund is greater than what would be required to hit the preferred return, then the net-of-fees NAV is adjusted for the expected portion that GPs will claim with carried interest.

This method creates an adjusted set of LP cash flows and adjusted-NAVs. These are used to calculate a PME (with Russell 3000 benchmark) and IRR, which are then compared to the vintage year breakpoints provided by Burgiss. The Burgiss breakpoints are provided yearly based on the time into the fund. To get intermediate values I interpolate between years. For example, the $75^{\text {th }}$ percentile breakpoint for a 1997 fund 9 quarters into the fund is calculated using the following:

$$
P M E_{\mathrm{Q} 9}^{\mathrm{P} 75, \mathrm{VY} 1997}=\frac{3}{4} P M E_{\mathrm{Q} 8}^{\mathrm{P} 75, \mathrm{VY} 1997}+\frac{1}{4} P M E_{\mathrm{Q} 12}^{\mathrm{P} 15, \mathrm{VY} 1997}
$$

The moments of PME Quartile and IRR Quartile performance calculated using this method are listed in Table 1. 


\section{Appendix B: Maximum Likelihood Estimation}

This appendix describes the likelihood equations used in Section 4.1 to estimate the relation between career concern variables and variance of subsequent investments. Each observation represents the outcome of a single portfolio company investment modeled with the following distribution:

$$
\begin{gathered}
P M E_{i, j}=\max \left[0, \mu_{i}+\grave{o}_{i, j}\right] \\
\grave{o}_{i, j} \sim N\left(0, \sigma_{i, j}^{2}\right) \\
\sigma_{i, j}^{2}=e^{\theta_{i}+\beta X_{i, j}}
\end{gathered}
$$

Equation 1 describes the observed performance of each portfolio company as being truncated at PME $=0$, and normally distributed around a mean that is exponentially related to a linear combination of GP and market characteristics at the time the investment is made. The variance of the error term,

$\sigma_{i, j}^{2}$, is treated as a latent variable that is determined by Equation 3. Taking logs of the normal distribution, the resulting log likelihood for each observation is given by:

$$
\ln \ell\left(\beta, \mu_{i}, \theta_{i} \mid P M E_{i, j}\right)= \begin{cases}-\frac{1}{2} \ln 2 \pi-\frac{1}{2}\left(\theta_{i}+\beta X_{i, j}\right)-\frac{\left(P M E_{i, j}-\mu_{i}\right)^{2}}{2 e^{\theta_{i}+\beta X_{i, j}}} & \text { if } P M E_{i, j}>0 \\ \ln \Phi\left[\frac{-\mu_{i}}{\frac{\left(\theta_{i}+\beta X_{i, j}\right)}{2}}\right] & \text { if } P M E_{i, j}=0\end{cases}
$$


The parameter estimates are determined by maximizing the following sum of Equation 4 using the lf method of likelihood maximization in Stata:

$$
\ln L\left(\beta, \mu_{i}, \theta_{i} \mid \ldots\right)=\sum_{i, j} \ln \ell\left(\beta, \mu_{i}, \theta_{i} \mid P M E_{i, j}\right)
$$




\section{Appendix C: Fund Performance and Fundraising Success at Alternative Times in Fund Life}

This appendix presents additional regression of fund performance on the likelihood of raising a new fund. The analysis mirrors Section 3.1 and Table 4, but is performed at different times in the fund's life. Table C1 presents the coefficient estimates from a linear probability model. The dependent variable takes the value 1, if the GP subsequently raised a follow-on fund. Panel A examines the cross-section of funds whose GP had not raised a new fund 2 years into the fund. Panel B considers a similar cross-section of funds 4 years into the fund.

The results on fund performance at 2 and 4 years broadly match those presented in Table 4. Fund performance, measured as either PME or PME Quartile, is positively related to the likelihood the GP will raise a new fund. The exceptions are the coefficient on PME Quartile in Panel B, when either Fund Loss Rate or Porffolio Company HHI is included in the regression. The results on Fund Loss Rate are weaker and only significant in Model 4 of Panel B. This is likely because only 2 years into the fund, a significant portion of the fund is likely to still be held at cost. In addition, GPs (on average) still have a significant amount of capital to deploy at three years into the fund, such that their loss ratio may change dramatically over time. The coefficients on Portfolio Company HHI are negative and strongly significant in every model except for Model 5 , which is consistent with the evidence in Table 4. 


\section{References}

Ai, C., Norton, E.C., 2003. Interaction Terms in Logit and Probit Models. Econ. Lett. 80, 123-129. doi:10.1016/S0165-1765(03)00032-6

Barrot, J.-N., 2016. Investor Horizon and the Life Cycle of Innovative Firms: Evidence from Venture Capital. Manage. Sci.

Braun, R., Jenkinson, T., Stoff, I., 2016. How Persistant is Private Equity Performance? J. financ. econ.

Brown, K.C., Harlow, W.V., Starks, L.T., 1996. Of Tournaments and Temptations: An Analysis of Managerial Incentives in the Mutual Fund Industry. J. Finance 51, 85-110. doi:10.2307/2329303

Brown, S.J., Goetzmann, W.N., Park, J., 2001. Careers and Survival: Competition and Risk in the Hedge Fund and CTA Industry. J. Finance 56, 1869-1886. doi:10.1111/0022-1082.00392

Chevalier, J., Ellison, G., 1997. Risk Taking by Mutual Funds as a Response to Incentives. J. Polit. Econ. 105, 1167-1200. doi:10.1086/516389

Chung, J.W., Sensoy, B.A., Stern, L., Weisbach, M.S., 2012. Pay For Performance From Future Fund Flows: The Case of Private Equity. Rev. Financ. Stud. doi:10.1093/rfs/hhr141

Gibbons, R., Murphy, K.J., 1992. Optimal Incentive Contracts in the Presence of Career Concerns: Theory and Evidence. J. Polit. Econ. 100, 468. doi:10.1086/261826

Goldberg, M., Wnek, R.E., Rodricks, P., Kruth, C., 2013. Untangling The Carried Interest Controversy. J. Bus. Econ. Res. 11, 89-96. doi:http://dx.doi.org/10.19030/jber.v11i2.7621

Harris, R.S., Jenkinson, T., Kaplan, S.N., 2014. Private Equity Performance: What Do We Know? J. Finance 69, 1851-1882. doi:10.1111/jofi.12154

Harvey, A.C., 1976. Estimating Regression Models with Multiplicative Heteroscedasticity. Econometrica 44, 461-465. doi:10.2307/1913974

Hellmann, T.F., Puri, M., 2002. Venture Capital and the Professionalization of Start-Up Firms: Empirical Evidence. J. Finance 57, 169-197. doi:10.1111/1540-6261.00419

Hellmann, T.F., Puri, M., 2000. The Interaction Between Product Market and Financing Strategy: The Role of Venture Capital. Rev. Financ. Stud. 13, 959-984. doi:10.1093/rfs/13.4.959

Hochberg, Y. V., Ljungqvist, A., Vissing-Jorgensen, A., 2014. Informational Holdup and Performance Persistence in Venture Capital. Rev. Financ. Stud. 27, 102-152. doi:10.1093/rfs/hht046

Holmström, B., 1982. Managerial Incentive Problems---A Dynamic Perspective, in: Essays in Economics and Management in Honour of Lars Wahlbeck. pp. 209-230. 
Jensen, M.C., 1989. Eclipse of the Public Corporation. Harv. Bus. Rev. 67, 61-74. doi:10.2139/ssrn.146149

Kaplan, S.N., Schoar, A., 2005. Private Equity Performance: Returns, Persistence, and Capital Flows. J. Finance 60, 1791-1824. doi:10.1111/j.1540-6261.2005.00780.x

Lerner, J., Shane, H., Tsai, A., 2003. Do Equity Financing Cycles Matter? Evidence From Biotechnology Alliances. J. financ. econ. doi:10.1016/S0304-405X(02)00256-8

Ljungqvist, A., Richardson, M., Wolfenzon, D., 2009. The Investment Behavior of Buyout Funds: Theory and Evidence, Working Paper. doi:10.2139/ssrn.972640

Lopez-de-Silanes, F., Phalippou, L., Gottschalg, O., 2015. Giants at the Gate: Investment Returns and Diseconomies of Scale in Private Equity. J. Financ. Quant. Anal. 50, 377-411. doi:10.1017/S0022109015000113

Lowry, M., Officer, M.S., Schwert, G.W., 2010. The Variability of IPO Initial Returns. J. Finance 65, 425-465. doi:10.1111/j.1540-6261.2009.01540.x

Metrick, A., Yasuda, A., 2010. The Economics of Private Equity Funds. Rev. Financ. Stud. 23, 2303-2341. doi:10.1093/rfs/hhq020

Nanda, R., Rhodes-Kropf, M., 2016. Financing Risk and Innovation. Manage. Sci. mnsc.2015.2350. doi:10.1287/mnsc.2015.2350

Nanda, R., Rhodes-Kropf, M., 2013. Investment Cycles and Startup Innovation. J. financ. econ. 110, 403-418. doi:10.1016/j.jfineco.2013.07.001

Ragazzo, 2015. Viewpoint: Do Loss Rates Indicate Risk in Private Equity [WWW Document]. URL http://www.abbottcapital.com/assets/Abbott-Viewpoint-Loss-Rates-September-19-2015.pdf (accessed 1.1.16).

Zwiebel, J., 1995. Corporate Conservatism and Relative Compensation. J. Polit. Econ. 103, 1. doi:10.1086/261973 


\section{Figure 1}

This figure depicts the relationship between fund performance and the increase in follow-on fund size. The increase in follow-on fund size is measured as a ratio between the committed capital of the follow-on fund and the committed capital of the current fund. Fund PME is measured in the quarter before the follow-on fund is raised. Funds that failed to raise a new fund are assigned a size increase of zero with their PME taken at the end of the fifth year of the fund. Estimation of smoothed conditional mean function and standard error bounds is accomplished via Loess method with polynomial of degree 2 and smoothing parameter 0.75 . Figure $1 \mathrm{~A}$ includes all funds in the sample. Figure 1B excludes funds with PME $>3$.

\section{A: All Funds}

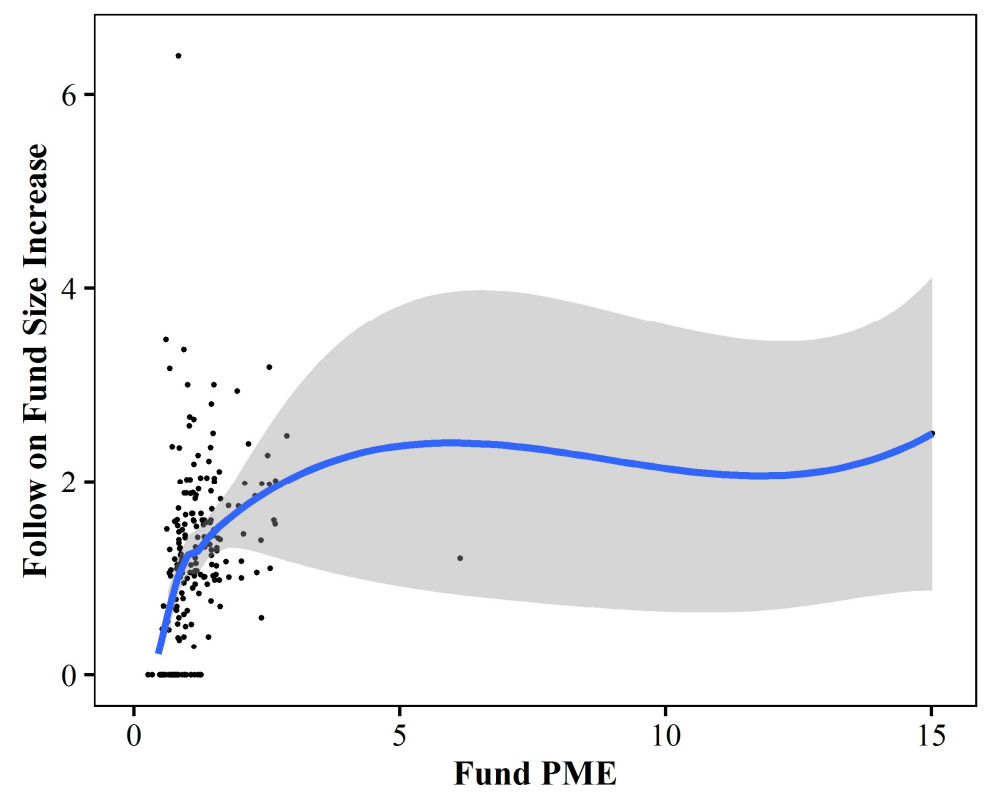

\section{B: PME > 3 Excluded}

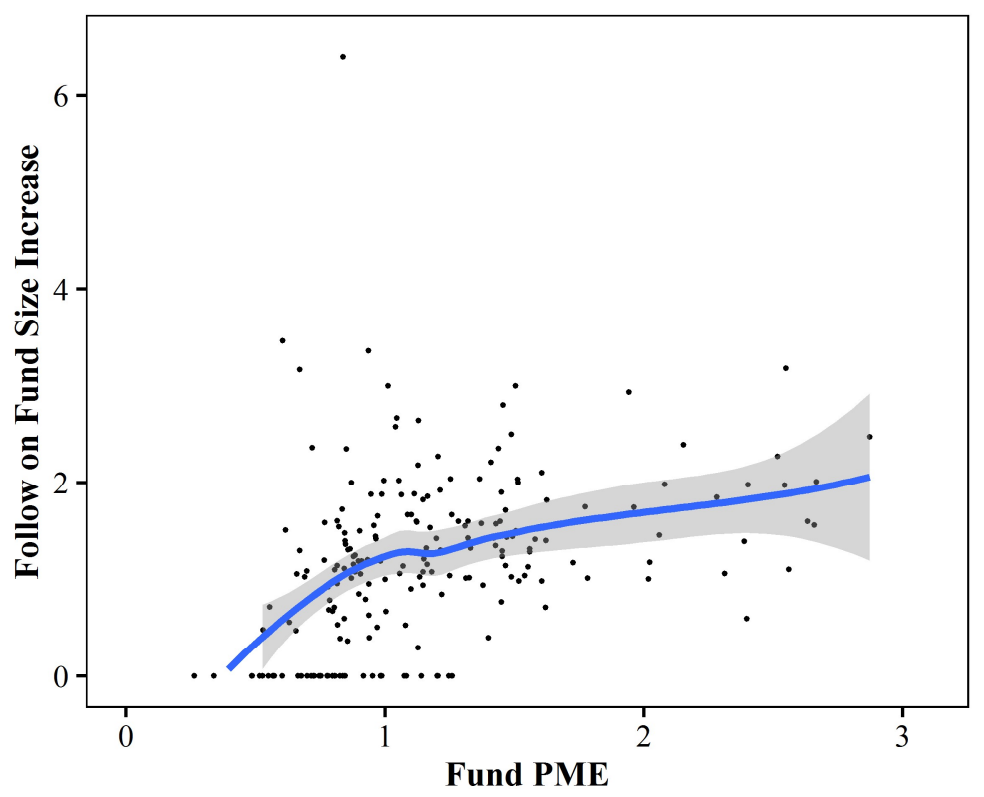




\section{Figure 2}

This figure depicts the relationship between interim fund performance and the increase in follow-on fund size, excluding funds for which the GP did not successfully raise a follow-on fund. The increase in follow-on fund size is measured as a ratio between the committed capital of the follow-on fund and the committed capital of the current fund. Fund PME is measured in the quarter before the follow-on fund is raised. Estimation of smoothed conditional mean function and standard error bounds is accomplished via Loess method with polynomial of degree 2 and smoothing parameter 0.75 . Figure $2 \mathrm{~A}$ includes all funds in the sample. Figure $2 \mathrm{~B}$ excludes funds with $\mathrm{PME}>3$.

\section{A: All Funds}

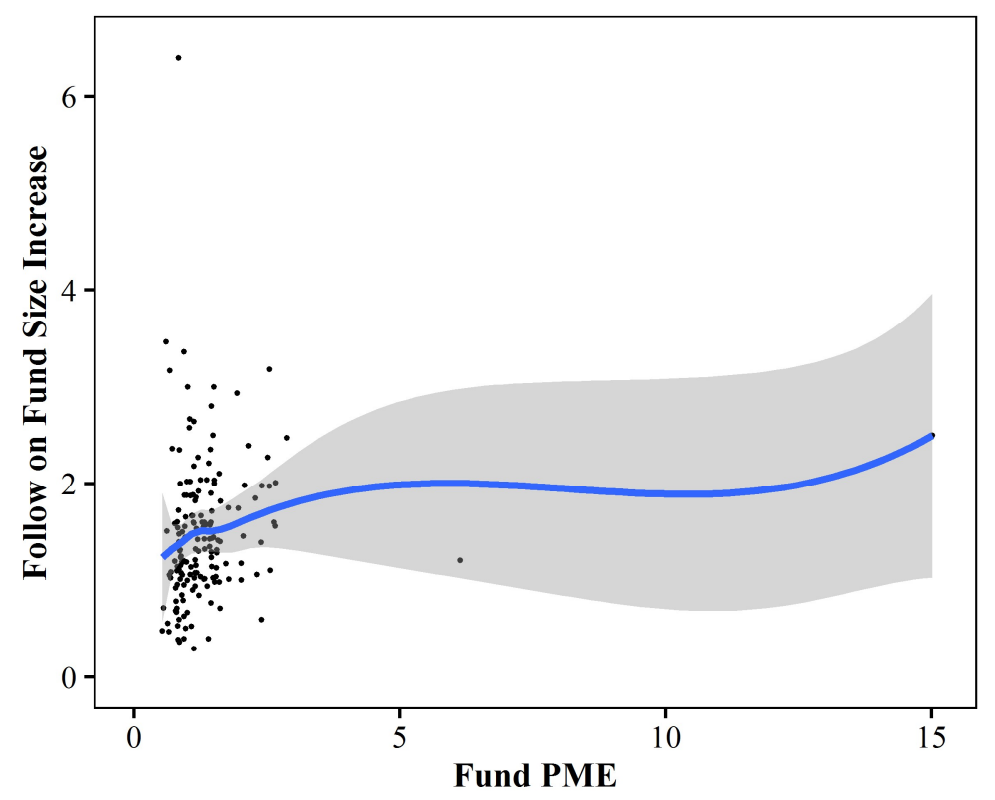

\section{B: PME > 3 Excluded}

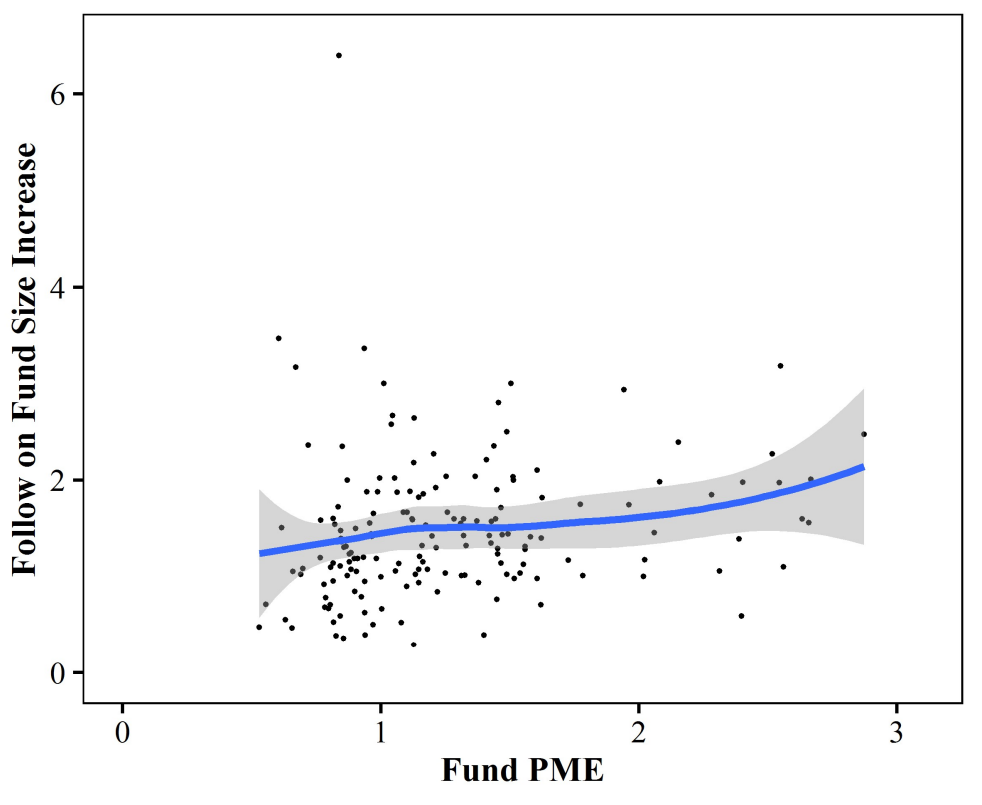




\section{Table 1}

\section{Venture Capital Fund Descriptive Statistics}

Descriptive statistics for the sample of 207 venture capital funds raised between 1981 and 2008. Panel A presents descriptive statistics for all funds in the sample. Previous Funds represents the number of venture capital funds operated by the GP prior to the current fund. Fund Size represents the capital committed to the fund and is listed in millions of dollars. Num of Investments is the number of portfolio company investments made by the fund. Raised Follow-on Fund presents the percentage of funds for which the GP successfully raised a follow-on fund. Measures of fund performance are reported as of the end of the data, June 30, 2015. For funds that are have not been fully liquidated by the end of the sample, the fund's NAV is added to the final cash flow. PME is gross public market equivalent, calculated using the method of Kaplan and Schoar (2005) with value-weighted NASDAQ stocks in CRSP as the public benchmark. IRR is the gross internal rate of return of the fund. PME Quartile and IRR Quartile represent the quartile of performance for each fund relative to its vintage year peers $(4=$ best performing quartile). Each quartile measure is calculated by adjusting gross cash flows for GP fees, as described in Appendix A, and comparing to vintage year benchmarks provided by Burgiss. Fund PME used for creating PME Quartile is calculated using the Russell 3000 index to match the quartile breakpoints provided by Burgiss. Loss Rate is defined as the ratio of aggregate dollar losses in investments with negative returns to total invested capital. Port. Company HHI is a Hirshman-Herfindahl index, which measures the concentration of fund value among portfolio company investments in the portfolio. Panel B presents statistics for 168 funds who successfully raised a follow-on fund. Year Follow-on Fund is Raised gives the time in years between the first observed close of the current fund and the closing of the Follow-on Fund. Size Increase is the ratio of capital committed to the follow-on fund divided by the committed capital of the current fund. Measures of fund performance in Panel B are measured the quarter prior to the first observed closing of the follow-on fund.

\begin{tabular}{|c|c|c|c|c|c|c|}
\hline & Mean & Median & $\begin{array}{c}\text { Standard } \\
\text { Deviation }\end{array}$ & Minimum & Maximum & $\mathrm{N}$ \\
\hline \multicolumn{7}{|l|}{ Panel A: Fund Observations } \\
\hline Previous Funds & 3.1 & 2.0 & 2.7 & 0.0 & 11.0 & 207 \\
\hline Fund Size (\$million) & 285.2 & 150.0 & 392.6 & 6.0 & $2,560.6$ & 207 \\
\hline Num of Investments & 33.9 & 29.0 & 20.1 & 5.0 & 123.0 & 207 \\
\hline Raised Follow-on Fund & $81.2 \%$ & & & & & \\
\hline \multicolumn{7}{|l|}{ Final Fund Performance (Q2 2015) } \\
\hline PME & 1.60 & 1.13 & 1.96 & 0.12 & 22.28 & 207 \\
\hline IRR & $28 \%$ & $15 \%$ & $83 \%$ & $-77 \%$ & $857 \%$ & 207 \\
\hline PME Quartile & 3.02 & 3.00 & 1.07 & 1.00 & 4.00 & 205 \\
\hline IRR Quartile & 2.84 & 3.00 & 1.18 & 1.00 & 4.00 & 205 \\
\hline Loss Rate & $42 \%$ & $41 \%$ & $17 \%$ & $4 \%$ & $91 \%$ & 207 \\
\hline Port. Company HHI & 0.19 & 0.14 & 0.16 & 0.01 & 1.00 & 207 \\
\hline \multicolumn{7}{|c|}{ Panel B: Follow-on Fund Observations } \\
\hline Year Follow-on Fund is Raised & 3.52 & 3.25 & 1.71 & 0.75 & 11.25 & 168 \\
\hline Size Increase & 1.49 & 1.38 & 0.74 & 0.29 & 6.39 & 168 \\
\hline \multicolumn{7}{|c|}{ Fund Performance Prior to Follow-on } \\
\hline PME & 1.37 & 1.15 & 1.23 & 0.53 & 15.02 & 168 \\
\hline IRR & $65 \%$ & $23 \%$ & $153 \%$ & $-13 \%$ & $1461 \%$ & 168 \\
\hline PME Quartile & 3.26 & 4.00 & 0.88 & 1.00 & 4.00 & 167 \\
\hline IRR Quartile & 2.91 & 3.00 & 1.23 & 1.00 & 4.00 & 167 \\
\hline Loss Rate & $8 \%$ & $4 \%$ & $10 \%$ & $0 \%$ & $44 \%$ & 168 \\
\hline Port. Company HHI & 0.11 & 0.08 & 0.10 & 0.02 & 0.81 & 168 \\
\hline
\end{tabular}


Table 2

\section{Portfolio Company Descriptive Statistics}

Descriptive statistics for the sample of 6,912 venture capital portfolio company investments initiated between 1981 and 2014 . Initial Investment (\$) reports the size in dollars of capital invested from the fund into each portfolio company over the first nine months of the investment. Initial Investment (\% Fund Size) reports the initial size of the investment as a fraction of the committed capital of the investing fund. Fund Age at Investment is the age of the fund in years at the time the portfolio company investment was initiated. Realized is the percentage of portfolio companies that had been exited by the end of the data in June 30, 2015. Holding Period is the time in years between when a portfolio company investment is initialized and when the fund exited the investment. Measures of individual investment performance are calculated as of the June 30, 2015. For unrealized investments, the final valuation of the fund's position is added to the final period cash flow to determine investment performance. PME is the public market equivalent of Kaplan and Schoar (2005) calculated using the NASDAQ composite as a public benchmark. IRR is the internal rate of return for each investment. MOIC is multiple of invested capital, defined as the ratio of cash flows from the investment to the fund, divided by the cash flows from the fund into the investment.

\begin{tabular}{|c|c|c|c|c|c|c|}
\hline & Mean & Median & $\begin{array}{c}\text { Standard } \\
\text { Deviation }\end{array}$ & Minimum & Maximum & $\mathrm{N}$ \\
\hline Initial Investment (\$) & $4,412,600$ & $2,300,982$ & $6,237,821$ & 25,000 & $90,000,000$ & 6,912 \\
\hline Initial Investment ( $\%$ Fund Size) & $1.6 \%$ & $1.2 \%$ & $1.6 \%$ & $0.0 \%$ & $26.3 \%$ & 6,912 \\
\hline Fund Age at Investment (Years) & 1.9 & 1.5 & 1.4 & 0.0 & 7.3 & 6,912 \\
\hline Realized & $91 \%$ & & & & & 6,912 \\
\hline Holding Period (Years) & 5.6 & 4.8 & 3.4 & 0.3 & 17.5 & 6,297 \\
\hline PME & 1.73 & 0.48 & 6.82 & 0.00 & 314.69 & 6,912 \\
\hline IRR & $2.6 \%$ & $-0.8 \%$ & $116.5 \%$ & $-100.0 \%$ & $1770.9 \%$ & 6,636 \\
\hline MOIC & 2.34 & 0.85 & 4.63 & 0.00 & 29.35 & 6,912 \\
\hline
\end{tabular}


Table 3

Follow-on Fund Size and Current Fund Performance

This table presents OLS regression estimates relating the size of the follow-on funds raised by 207 venture capital partnerships to the performance and characteristics of the current fund. The dependent variable is the Size Increase of the follow-on fund measured as the ratio of the committed capital to the follow-on fund divided by the committed capital of the current fund. Fund Performance $t_{t-1}$ is the interim performance of the fund. For GPs who successfully raise a new fund this is taken the quarter prior the first closing date of the follow-on fund. For funds that failed to raise a new fund, performance is calculated 5 years into the current fund. In Models 1, 2, 4 and 5 fund performance is measured using the PME measure of Kaplan and Schoar (2005) with the value weighted returns to NASDAQ stocks used as the benchmark. Models 3 and 6 include fund performance expressed as PME Quartile (4 as highest performing quartile), benchmarked using vintage year breakpoints provided by Burgiss. Ln(Fund Size) is the natural logarithm of capital committed to the current fund measured in millions of dollars. GP Experience is the natural logarithm of one plus the previous funds operated by the GP. Models 1,2, 4 and 5 include fixed effects for the vintage year of the current fund. Panel A presents results for all 207 venture capital funds in the sample described in Table 1, with Size Increase set to zero for funds who failed to raise a follow-on fund. Panel B presents results for a sample restricted to 168 funds that successfully raised a follow-on fund. Robust standard errors are reported in parentheses. *,** and *** represent significance at the $10 \%, 5 \%$ and $1 \%$ level respectively.

\begin{tabular}{|c|c|c|c|c|c|c|}
\hline \multicolumn{7}{|l|}{ Panel A: All Funds } \\
\hline Fund Performance Measure: & $\begin{array}{c}\text { PME } \\
\text { Model } 1 \\
\end{array}$ & $\begin{array}{c}\text { PME } \\
\text { Model } 2 \\
\end{array}$ & $\begin{array}{c}\text { PME Quartile } \\
\text { Model } 3 \\
\end{array}$ & $\begin{array}{c}\text { PME } \\
\text { Model } 4 \\
\end{array}$ & $\begin{array}{c}\text { PME } \\
\text { Model } 5 \\
\end{array}$ & $\begin{array}{c}\text { PME Quartile } \\
\text { Model } 6\end{array}$ \\
\hline Fund Performance $_{\mathrm{t}-1}$ & $\begin{array}{c}0.12^{* * *} \\
(0.043)\end{array}$ & $\begin{array}{l}0.50^{* *} \\
(0.20)\end{array}$ & $\begin{array}{l}0.34 * * * \\
(0.052)\end{array}$ & $\begin{array}{c}0.20 \\
(0.20)\end{array}$ & $\begin{array}{c}0.42^{* *} \\
(0.19)\end{array}$ & $\begin{array}{c}0.46^{* * *} \\
(0.087)\end{array}$ \\
\hline Fund Performance ${ }_{\mathrm{t}-1}^{2}$ & & $\begin{array}{c}-0.028^{* *} \\
(0.011)\end{array}$ & & & $\begin{array}{c}-0.038^{* * *} \\
(0.012)\end{array}$ & \\
\hline GP Experience & $\begin{array}{l}0.091 \\
(0.11)\end{array}$ & $\begin{array}{l}0.094 \\
(0.11)\end{array}$ & $\begin{array}{l}0.22 * * \\
(0.096)\end{array}$ & $\begin{array}{c}0.16 \\
(0.16)\end{array}$ & $\begin{array}{c}-0.097 \\
(0.16)\end{array}$ & $\begin{array}{c}0.59^{* *} \\
(0.24)\end{array}$ \\
\hline GP Experience $*$ Fund Performance $e_{t-1}$ & & & & $\begin{array}{l}-0.057 \\
(0.13)\end{array}$ & $\begin{array}{c}0.16 \\
(0.11)\end{array}$ & $\begin{array}{l}-0.12^{*} \\
(0.068)\end{array}$ \\
\hline $\operatorname{Ln}($ Current Fund Commited Capital) & $\begin{array}{c}-0.010 \\
(0.13)\end{array}$ & $\begin{array}{c}-0.0012 \\
(0.13)\end{array}$ & $\begin{array}{c}-0.18^{* *} \\
(0.079)\end{array}$ & $\begin{array}{l}-0.010 \\
(0.13)\end{array}$ & $\begin{array}{c}0.0012 \\
(0.12)\end{array}$ & $\begin{array}{c}-0.20 * * \\
(0.080)\end{array}$ \\
\hline Constant & $\begin{array}{c}1.14 \\
(2.38)\end{array}$ & $\begin{array}{c}0.56 \\
(2.41)\end{array}$ & $\begin{array}{c}3.33^{* *} \\
(1.42)\end{array}$ & $\begin{array}{l}1.04 \\
(2.39)\end{array}$ & $\begin{array}{c}0.63 \\
(2.40)\end{array}$ & $\begin{array}{c}3.25^{* *} \\
(1.41)\end{array}$ \\
\hline $\begin{array}{l}\text { Observations } \\
\mathrm{R}^{2} \\
\text { Vintage Year FE }\end{array}$ & $\begin{array}{c}207 \\
0.065 \\
\text { Yes }\end{array}$ & $\begin{array}{c}207 \\
0.115 \\
\text { Yes }\end{array}$ & $\begin{array}{c}205 \\
0.158 \\
\text { No }\end{array}$ & $\begin{array}{c}207 \\
0.066 \\
\text { Yes }\end{array}$ & $\begin{array}{c}207 \\
0.081 \\
\text { Yes }\end{array}$ & $\begin{array}{c}205 \\
0.167 \\
\text { No }\end{array}$ \\
\hline \multicolumn{7}{|l|}{ Panel B: Successful Follow-on Fundraisers } \\
\hline Fund Performance Measure: & $\begin{array}{c}\text { PME } \\
\text { Model } 1 \\
\end{array}$ & $\begin{array}{c}\text { PME } \\
\text { Model } 2 \\
\end{array}$ & $\begin{array}{c}\text { PME Quartile } \\
\text { Model } 3 \\
\end{array}$ & $\begin{array}{c}\text { PME } \\
\text { Model } 4 \\
\end{array}$ & $\begin{array}{c}\text { PME } \\
\text { Model } 5 \\
\end{array}$ & $\begin{array}{c}\text { PME Quartile } \\
\text { Model } 6 \\
\end{array}$ \\
\hline Fund Performance $_{\mathrm{t}-1}$ & $\begin{array}{l}0.0054 \\
(0.034)\end{array}$ & $\begin{array}{l}-0.067 \\
(0.17)\end{array}$ & $\begin{array}{l}0.15^{* * *} \\
(0.053)\end{array}$ & $\begin{array}{c}-0.17 * \\
(0.092)\end{array}$ & $\begin{array}{l}-0.14 \\
(0.16)\end{array}$ & $\begin{array}{l}0.25^{* *} \\
(0.098)\end{array}$ \\
\hline Fund Performance ${ }_{\mathrm{t}-1}^{2}$ & & $\begin{array}{l}0.0051 \\
(0.010)\end{array}$ & & & $\begin{array}{l}-0.0045 \\
(0.012)\end{array}$ & \\
\hline GP Experience & $\begin{array}{c}0.13 \\
(0.096)\end{array}$ & $\begin{array}{c}0.13 \\
(0.097)\end{array}$ & $\begin{array}{l}0.22 * * \\
(0.087)\end{array}$ & $\begin{array}{l}-0.031 \\
(0.087)\end{array}$ & $\begin{array}{l}-0.061 \\
(0.12)\end{array}$ & $\begin{array}{c}0.52^{* *} \\
(0.26)\end{array}$ \\
\hline GP Experience * Fund Performance $\mathrm{t}_{\mathrm{t}-1}$ & & & & $\begin{array}{l}0.13^{* *} \\
(0.051)\end{array}$ & $\begin{array}{c}0.15^{* * *} \\
(0.051)\end{array}$ & $\begin{array}{l}-0.091 \\
(0.071)\end{array}$ \\
\hline Ln(Current Fund Commited Capital) & $\begin{array}{c}-0.31^{* *} \\
(0.13)\end{array}$ & $\begin{array}{c}-0.32^{* *} \\
(0.14)\end{array}$ & $\begin{array}{c}-0.29 * * * \\
(0.080)\end{array}$ & $\begin{array}{c}-0.33^{* *} \\
(0.13)\end{array}$ & $\begin{array}{c}-0.33^{* *} \\
(0.14)\end{array}$ & $\begin{array}{c}-0.30 * * * \\
(0.082)\end{array}$ \\
\hline Constant & $\begin{array}{c}7.23 * * * \\
(2.37)\end{array}$ & $\begin{array}{l}7.50^{* *} \\
(2.72)\end{array}$ & $\begin{array}{c}6.18^{* * *} \\
(1.50)\end{array}$ & $\begin{array}{c}7.83^{* * *} \\
(2.40)\end{array}$ & $\begin{array}{c}7.71 * * * \\
(2.66)\end{array}$ & $\begin{array}{c}6.06^{* * *} \\
(1.50)\end{array}$ \\
\hline $\begin{array}{l}\text { Observations } \\
\mathrm{R}^{2} \\
\text { Vintage Year FE }\end{array}$ & $\begin{array}{c}168 \\
0.081 \\
\text { Yes }\end{array}$ & $\begin{array}{c}168 \\
0.072 \\
\text { Yes }\end{array}$ & $\begin{array}{c}167 \\
0.115 \\
\text { No }\end{array}$ & $\begin{array}{c}168 \\
0.080 \\
\text { Yes }\end{array}$ & $\begin{array}{c}168 \\
0.087 \\
\text { Yes }\end{array}$ & $\begin{array}{c}167 \\
0.120 \\
\text { No }\end{array}$ \\
\hline
\end{tabular}


Table 4

Existence of a Follow-on Fund and Fund Performance

This table reports linear probability model estimates of the relationship between interim fund performance and successful raising of a follow-on fund. Panel A consists of the 147 funds who had not yet raised a follow-on fund by the third year of the fund's operation. The dependent variable takes the value 1 for funds who subsequently raise a follow on fund following. Fund Performance and GP Experience are measured as described in the previous table. Loss Rate is defined as the aggregate sum of losses in portfolio companies divided by the committed capital of the fund. Port.Company HHI is a

Herfindahl-Hirshman index formed using the contribution of each portfolio company to the fund's value in the manner described in Section 2.1. Models 2, 4 and 6, which use PME as the measure of performance include vintage year fixed effects. Robust standard errors are reported in parentheses. *, ** and $* * *$ represent significance at the $10 \%, 5 \%$ and $1 \%$ level respectively.

\begin{tabular}{|c|c|c|c|c|c|c|}
\hline Fund Performance Measure: & $\begin{array}{c}\text { PME } \\
\text { Model } 1\end{array}$ & $\begin{array}{c}\text { PME Quartile } \\
\text { Model } 2\end{array}$ & $\begin{array}{c}\text { PME } \\
\text { Model } 3\end{array}$ & $\begin{array}{l}\text { PME Quartile } \\
\text { Model } 4\end{array}$ & $\begin{array}{c}\text { PME } \\
\text { Model } 5\end{array}$ & $\begin{array}{c}\text { PME Quartile } \\
\text { Model } 6\end{array}$ \\
\hline Fund Performance $_{\mathrm{t}=3}$ & $\begin{array}{c}0.82^{* * *} \\
(0.17)\end{array}$ & $\begin{array}{c}0.25^{* * *} \\
(0.048)\end{array}$ & $\begin{array}{c}0.76^{* * * *} \\
(0.18)\end{array}$ & $\begin{array}{c}0.22^{* * * *} \\
(0.050)\end{array}$ & $\begin{array}{c}1.09 * * * \\
(0.18)\end{array}$ & $\begin{array}{c}0.24 * * * \\
(0.049)\end{array}$ \\
\hline GP Experience & $\begin{array}{c}0.55^{* * *} \\
(0.14)\end{array}$ & $\begin{array}{c}0.42^{* * *} \\
(0.13)\end{array}$ & $\begin{array}{c}0.49^{* * *} \\
(0.13)\end{array}$ & $\begin{array}{c}0.42^{* * *} \\
(0.13)\end{array}$ & $\begin{array}{c}0.52^{* * *} \\
(0.13)\end{array}$ & $\begin{array}{c}0.34^{* * *} \\
(0.13)\end{array}$ \\
\hline GP Experience $*$ Fund Performance $\mathrm{t}_{\mathrm{t}=3}$ & $\begin{array}{c}-0.41 * * * \\
(0.097)\end{array}$ & $\begin{array}{c}-0.13^{* * *} \\
(0.042)\end{array}$ & $\begin{array}{c}-0.37^{* * *} \\
(0.10)\end{array}$ & $\begin{array}{c}-0.13^{* * *} \\
(0.041)\end{array}$ & $\begin{array}{c}-0.50^{* * *} \\
(0.084)\end{array}$ & $\begin{array}{c}-0.12^{* * *} \\
(0.042)\end{array}$ \\
\hline Loss Rate $_{\mathrm{t}=3}$ & & & $\begin{array}{c}-1.36 * * \\
(0.61)\end{array}$ & $\begin{array}{c}-1.40^{* *} \\
(0.64)\end{array}$ & & \\
\hline Port. Company $\mathrm{HHI}_{\mathrm{t}=3}$ & & & & & $\begin{array}{c}-1.81^{* * *} \\
(0.60)\end{array}$ & $\begin{array}{c}-1.17 * * * \\
(0.41)\end{array}$ \\
\hline Constant & $\begin{array}{l}-0.23 \\
(0.20)\end{array}$ & $\begin{array}{l}0.032 \\
(0.15)\end{array}$ & $\begin{array}{c}0.86 \\
(0.54)\end{array}$ & $\begin{array}{l}1.10 * * \\
(0.53)\end{array}$ & $\begin{array}{l}-0.18 \\
(0.17)\end{array}$ & $\begin{array}{c}0.23 \\
(0.17)\end{array}$ \\
\hline Observations & 147 & 145 & 147 & 145 & 147 & 145 \\
\hline $\mathrm{R}^{2}$ & 0.130 & 0.142 & 0.143 & 0.172 & 0.214 & 0.184 \\
\hline Vintage Years Fixed Effects & Yes & No & Yes & No & Yes & No \\
\hline
\end{tabular}


Table 5

Time to Raise Follow-on Fund and Fund Performance

This table presents Cox proportional hazard model estimates relating the speed at which venture capital firms raise a follow-on fund, conditional on the performance of their current fund. The sample consists of 207 venture capital funds raised between 1981and 2008. A spell of survival is defined as the number of quarters from initiation of the current fund until a new fund is raised by the GP. Num of VCFunds Raised $t_{t-1}$ is defined at the number of new venture capital funds listed in Preqin for the year prior to the current fund. The remaining explanatory variables are defined as in previous tables. Models 1,3 and 5 are stratified according to the vintage years of each fund. Coefficients from the model are reported as hazard ratios with the corresponding robust standard errors reported in parentheses. ${ }^{*}, * *$ and $* * *$ represent significance at the $10 \%, 5 \%$ and $1 \%$ level respectively.

\begin{tabular}{|c|c|c|c|c|c|c|}
\hline Fund Performance Measure: & $\begin{array}{c}\text { PME } \\
\text { Model } 1 \\
\end{array}$ & $\begin{array}{c}\text { PME Quartile } \\
\text { Model } 2 \\
\end{array}$ & $\begin{array}{c}\text { PME } \\
\text { Model } 3 \\
\end{array}$ & $\begin{array}{c}\text { PME Quartile } \\
\text { Model } 4 \\
\end{array}$ & $\begin{array}{c}\text { PME } \\
\text { Model } 5 \\
\end{array}$ & $\begin{array}{c}\text { PME Quartile } \\
\text { Model } 6 \\
\end{array}$ \\
\hline Fund Performance $e_{t-1}$ & $\begin{array}{l}1.79 * * \\
(0.41)\end{array}$ & $\begin{array}{c}2.05^{* * *} \\
(0.30)\end{array}$ & $\begin{array}{c}1.73^{* * * *} \\
(0.36)\end{array}$ & $\begin{array}{c}1.86^{* * * *} \\
(0.31)\end{array}$ & $\begin{array}{c}3.07 * * * \\
(0.79)\end{array}$ & $\begin{array}{c}2.07 * * * \\
(0.32)\end{array}$ \\
\hline GP Experience & $\begin{array}{c}2.33 * * * \\
(0.53)\end{array}$ & $\begin{array}{c}1.36 \\
(0.52)\end{array}$ & $\begin{array}{c}2.17 * * * \\
(0.48)\end{array}$ & $\begin{array}{l}1.37 \\
(0.57)\end{array}$ & $\begin{array}{c}2.06^{* * *} \\
(0.51)\end{array}$ & $\begin{array}{c}1.17 \\
(0.46)\end{array}$ \\
\hline GP Experience $*$ Fund Performance $\mathrm{t}_{\mathrm{t}-1}$ & $\begin{array}{c}0.75^{* *} \\
(0.11)\end{array}$ & $\begin{array}{c}0.97 \\
(0.11)\end{array}$ & $\begin{array}{l}0.75^{* *} \\
(0.100)\end{array}$ & $\begin{array}{l}0.98 \\
(0.12)\end{array}$ & $\begin{array}{l}0.63^{* * *} \\
(0.098)\end{array}$ & $\begin{array}{c}0.98 \\
(0.11)\end{array}$ \\
\hline Loss Rate $_{\mathrm{t}-1}$ & & & $\begin{array}{c}0.018^{* * *} \\
(0.017)\end{array}$ & $\begin{array}{c}0.039 \text { *** } \\
(0.034)\end{array}$ & & \\
\hline Port. Company $\mathrm{HHI}_{\mathrm{t}-1}$ & & & & & $\begin{array}{c}0.0041 * * * \\
(0.0061)\end{array}$ & $\begin{array}{c}0.075^{* *} \\
(0.093)\end{array}$ \\
\hline Num. of VC Funds Raised ${ }_{t-1}$ & $\begin{array}{c}1.01 * * \\
(0.0025)\end{array}$ & $\begin{array}{c}1.00 * * \\
(0.00059)\end{array}$ & $\begin{array}{c}1.00 * * \\
(0.0025)\end{array}$ & $\begin{array}{c}1.00 * * * \\
(0.00063)\end{array}$ & $\begin{array}{c}1.01 * \\
(0.0027)\end{array}$ & $\begin{array}{c}1.00^{* * *} \\
(0.00060)\end{array}$ \\
\hline Funds & 207 & 205 & 207 & 205 & 207 & 205 \\
\hline Fund-Quarters & 5,342 & 5,199 & 5,342 & 5,199 & 5,342 & 5,199 \\
\hline Pseudo- $\mathrm{R}^{2}$ & 0.041 & 0.065 & 0.064 & 0.074 & 0.068 & 0.070 \\
\hline Stratified by Vintage Year & Yes & No & Yes & No & Yes & No \\
\hline
\end{tabular}


Table 6

\section{Maximum Likelihood Estimates of Fund Performance and Portfolio Company Variance}

This table presents the maximum likelihood estimates of the cross-sectional relationship between venture capital portfolio company variance and career concern variables. The sample consists of all portfolio company investments made after the first year of the fund for 207 venture capital funds raised between 1981 and 2007. The dependent variable is the final PME of each portfolio company investment benchmarked with the value-weighted returns of NASDAQ stocks in CRSP. The likelihood function is described in Section 4.1 and Appendix B. Each model presents the estimates from the variance equation of the likelihood function. Years into the Fund is measured as the number of years from the first closing of the fund until the investment is initiated. The remaining explanatory variables are defined as in previous tables. Each Model contains dummy variables at the GP-level in both the mean and variance equations. Goodness of fit is measured relative to a model which includes only GP dummy variables in the mean and variance equation using the Pseudo- $\mathrm{R}^{2}$ proposed by McFadden (1973). Standard errors are reported in parentheses. *,** and *** represent significance at the $10 \%, 5 \%$ and $1 \%$ level respectively.

\begin{tabular}{|c|c|c|c|c|c|c|}
\hline Fund Performance Measure: & $\begin{array}{c}\text { PME } \\
\text { Model } 1 \\
\end{array}$ & $\begin{array}{c}\text { PME Quartile } \\
\text { Model } 2 \\
\end{array}$ & $\begin{array}{c}\text { PME } \\
\text { Model } 3 \\
\end{array}$ & $\begin{array}{c}\text { PME Quartile } \\
\text { Model } 4 \\
\end{array}$ & $\begin{array}{c}\text { PME } \\
\text { Model } 5 \\
\end{array}$ & $\begin{array}{c}\text { PME Quartile } \\
\text { Model } 6\end{array}$ \\
\hline Fund Performance $e_{t-1}$ & $\begin{array}{c}0.23^{* * *} \\
(0.075)\end{array}$ & $\begin{array}{c}0.12^{* * *} \\
(0.031)\end{array}$ & $\begin{array}{l}0.15^{* *} \\
(0.073)\end{array}$ & $\begin{array}{c}0.075^{* *} \\
(0.034)\end{array}$ & $\begin{array}{c}0.21 * * * \\
(0.077)\end{array}$ & $\begin{array}{c}0.12^{* * *} \\
(0.031)\end{array}$ \\
\hline $\operatorname{Ln}(1+$ Years Into Fund $)$ & $\begin{array}{c}0.027 \\
(0.079)\end{array}$ & $\begin{array}{l}-0.14 * \\
(0.086)\end{array}$ & $\begin{array}{c}0.37^{* * *} \\
(0.11)\end{array}$ & $\begin{array}{l}0.22 * \\
(0.12)\end{array}$ & $\begin{array}{c}0.064 \\
(0.086)\end{array}$ & $\begin{array}{l}-0.078 \\
(0.091)\end{array}$ \\
\hline GP Experience & $\begin{array}{c}-0.83^{* * *} \\
(0.085)\end{array}$ & $\begin{array}{c}-0.87 * * * \\
(0.086)\end{array}$ & $\begin{array}{c}-0.67^{* * *} \\
(0.092)\end{array}$ & $\begin{array}{c}-0.71 * * * \\
(0.095)\end{array}$ & $\begin{array}{c}-0.82^{* * *} \\
(0.086)\end{array}$ & $\begin{array}{c}-0.84 * * * \\
(0.087)\end{array}$ \\
\hline Loss Rate $_{\mathrm{t}-1}$ & & & $\begin{array}{c}-1.50^{* * *} \\
(0.30)\end{array}$ & $\begin{array}{c}-1.31 * * * \\
(0.32)\end{array}$ & & \\
\hline Port. Company $\mathrm{HHI}_{\mathrm{t}-1}$ & & & & & $\begin{array}{c}0.40 \\
(0.36)\end{array}$ & $\begin{array}{l}0.69 * \\
(0.36)\end{array}$ \\
\hline Observations & 4,877 & 4,800 & 4,877 & 4,800 & 4,877 & 4,800 \\
\hline $\begin{array}{l}\text { Pseudo-R }{ }^{2} \\
\text { GP Dummies }\end{array}$ & $\begin{array}{c}0.014 \\
\text { Yes }\end{array}$ & $\begin{array}{c}0.014 \\
\text { Yes }\end{array}$ & $\begin{array}{c}0.016 \\
\text { Yes }\end{array}$ & $\begin{array}{c}0.016 \\
\text { Yes }\end{array}$ & $\begin{array}{c}0.016 \\
\text { Yes }\end{array}$ & $\begin{array}{c}0.014 \\
\text { Yes }\end{array}$ \\
\hline
\end{tabular}




\section{Table 7}

\section{Fund Performance and Portfolio Company Investment Size}

This table presents OLS estimates of the relationship between fund performance the size of subsequent portfolio company investments for a sample of 207 venture capital funds raised between 1981 and 2008. The sample excluded investments made during the first year of the fund and investments made during the last quarter when the fund is observed making a new investment. The dependent variable is the cumulative cost of each investment over the first 9 months of the investment. Fund Performance is measured the quarter before the investment was initiated using PME or PME Quartile. Ln(Fund Size) is the natural log of the committed capital of each fund measured in millions of dollars. Each regression includes fixed effects for the GP making the investment. The remaining explanatory variables are defines as in previous tables. Standard errors reported beneath each coefficient are calculated by clustering by GP. *,** and *** represent significance at the $10 \%, 5 \%$ and $1 \%$ level respectively.

\begin{tabular}{|c|c|c|c|c|c|c|}
\hline Fund Performance Measure: & $\begin{array}{c}\text { PME } \\
\text { Model } 1\end{array}$ & $\begin{array}{c}\text { PME Quartile } \\
\text { Model } 2\end{array}$ & $\begin{array}{c}\text { PME } \\
\text { Model } 3\end{array}$ & $\begin{array}{c}\text { PME Quartile } \\
\text { Model } 4\end{array}$ & $\begin{array}{c}\text { PME } \\
\text { Model } 5\end{array}$ & $\begin{array}{c}\text { PME Quartile } \\
\text { Model } 6\end{array}$ \\
\hline Fund Performance $e_{t-1}$ & $\begin{array}{c}0.25^{* * *} \\
(0.088)\end{array}$ & $\begin{array}{c}0.11^{* * *} \\
(0.032)\end{array}$ & $\begin{array}{l}0.21 * * \\
(0.091)\end{array}$ & $\begin{array}{c}0.084 * * \\
(0.032)\end{array}$ & $\begin{array}{l}0.21 * * \\
(0.086)\end{array}$ & $\begin{array}{c}0.11^{* * *} \\
(0.031)\end{array}$ \\
\hline $\operatorname{Ln}(1+$ Years Into Fund $)$ & $\begin{array}{c}-0.29 * * * \\
(0.076)\end{array}$ & $\begin{array}{c}-0.44^{* * *} \\
(0.088)\end{array}$ & $\begin{array}{l}-0.15^{*} \\
(0.088)\end{array}$ & $\begin{array}{c}-0.29 * * \\
(0.11)\end{array}$ & $\begin{array}{c}-0.24 * * * \\
(0.087)\end{array}$ & $\begin{array}{c}-0.36^{* * *} \\
(0.098)\end{array}$ \\
\hline GP Experience & $\begin{array}{c}-0.36^{* * *} \\
(0.14)\end{array}$ & $\begin{array}{c}-0.36^{* *} \\
(0.14)\end{array}$ & $\begin{array}{c}-0.33^{* *} \\
(0.13)\end{array}$ & $\begin{array}{c}-0.33^{* *} \\
(0.14)\end{array}$ & $\begin{array}{c}-0.35^{* * *} \\
(0.13)\end{array}$ & $\begin{array}{c}-0.34 * * \\
(0.13)\end{array}$ \\
\hline $\operatorname{Ln}($ Fund Size $)$ & $\begin{array}{l}-0.031 \\
(0.22)\end{array}$ & $\begin{array}{c}-0.044 \\
(0.22)\end{array}$ & $\begin{array}{l}-0.030 \\
(0.22)\end{array}$ & $\begin{array}{l}-0.036 \\
(0.23)\end{array}$ & $\begin{array}{l}-0.041 \\
(0.20)\end{array}$ & $\begin{array}{c}-0.064 \\
(0.21)\end{array}$ \\
\hline Loss Rate $_{\mathrm{t}-1}$ & & & $\begin{array}{c}-0.96^{* * *} \\
(0.30)\end{array}$ & $\begin{array}{c}-0.80^{* *} \\
(0.31)\end{array}$ & & \\
\hline Port. Company $\mathrm{HHI}_{\mathrm{t}-1}$ & & & & & $\begin{array}{c}0.80 \\
(0.58)\end{array}$ & $\begin{array}{l}1.09 * \\
(0.55)\end{array}$ \\
\hline Observations & 4,575 & 4,500 & 4,575 & 4,500 & 4,575 & 4,500 \\
\hline $\begin{array}{l}\mathrm{R}^{2} \\
\text { GP Dummies }\end{array}$ & $\begin{array}{c}0.068 \\
\text { Yes }\end{array}$ & $\begin{array}{c}0.073 \\
\text { Yes }\end{array}$ & $\begin{array}{c}0.072 \\
\text { Yes }\end{array}$ & $\begin{array}{c}0.075 \\
\text { Yes }\end{array}$ & $\begin{array}{c}0.069 \\
\text { Yes }\end{array}$ & $\begin{array}{c}0.075 \\
\text { Yes }\end{array}$ \\
\hline
\end{tabular}




\section{Appendix Table C1}

\section{Existence of Follow on Fund and Fund Performance (2 Years and 4 Years)}

This table reports linear probability model estimates of the relationship between interim fund performance and successful raising of a followon fund. Panel A consists of the 176 fund's who had not yet raised a follow-on fund by the second year of the fund's operation. Panel B repeats the analysis in with fund's who had not raised a follow-on fund by the fourth year of fund operation. In each panel the dependent variable takes the value 1 for funds who subsequently raise a follow-on fund following the sample cutoff. Fund Performance is measured as either PME or PME Quartile in the relevant year. GP Experience is measured as the natural logarithm of on plus the number of previous funds operated by the GP. Loss Rate is defined as the aggregate sum of losses in portfolio companies divided by the committed capital of the fund. Port.Company HHI is a Herfindahl-Hirshman index formed using the contribution of each portfolio company to the fund's value in the manner described in Section 2.1. Models 1, 3 and 5, which use PME as the measure of performance include vintage year fixed effects. Robust standard errors are reported in parentheses. ${ }^{*}, * *$ and ${ }^{* * *}$ represent significance at the $10 \%, 5 \%$ and $1 \%$ level respectively.

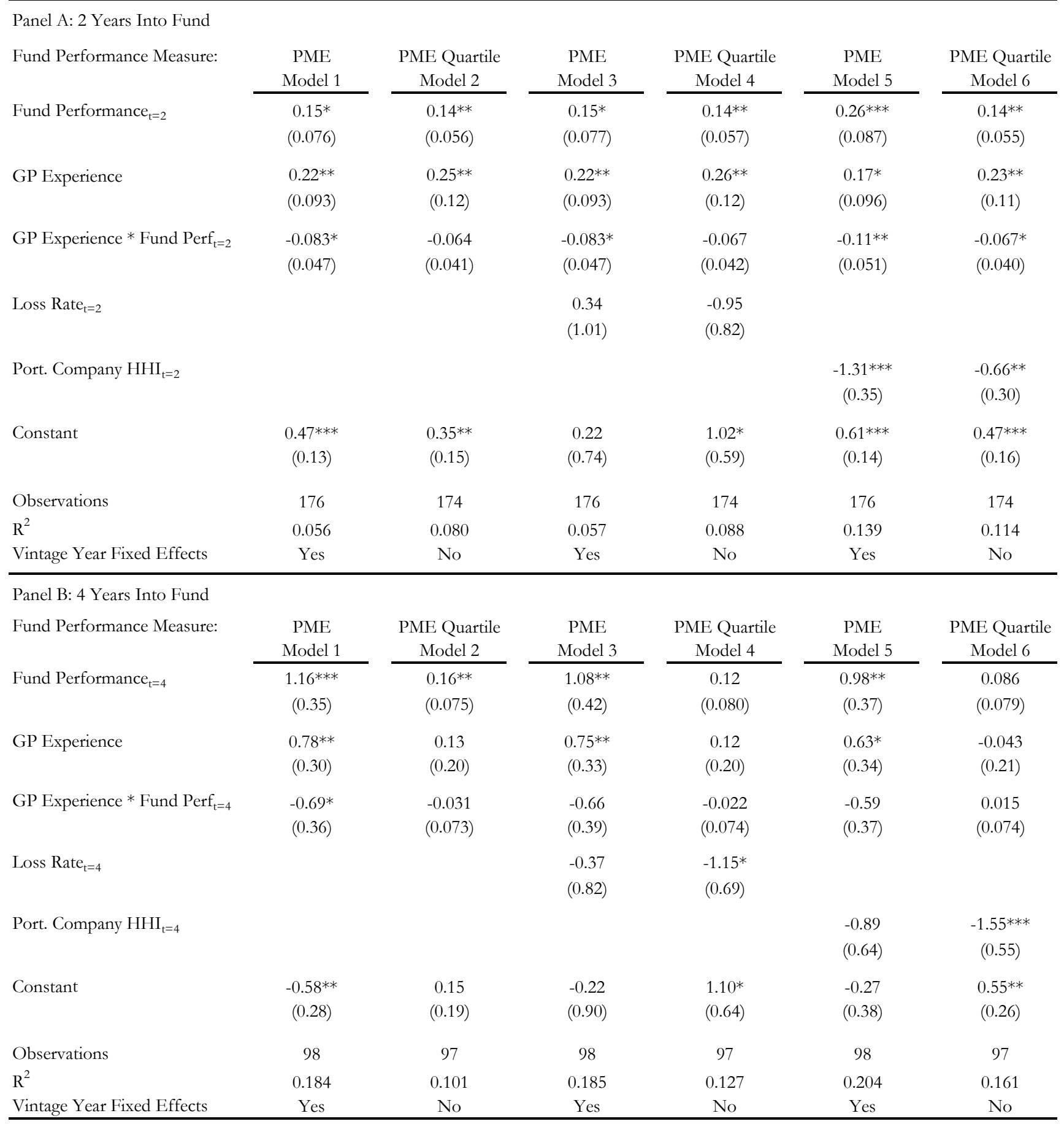

